\title{
Coastal Lagoons and Climate Change: Ecological and Social Ramifications in U.S. Atlantic and Gulf Coast Ecosystems
}

\author{
$\underline{\text { Abigail Anthony }}^{1}, \underline{\text { Joshua Atwood }}^{1}, \underline{\text { Peter August }}^{1}$, Carrie Byron $^{1}$, Stanley Cobb ${ }^{1}$ Cheryl Foster $^{1}$, \\ $\underline{\text { Crystal Fry }}^{1}$, Arthur Gold $^{1}$, Kifle Hagos ${ }^{1}$, Leanna Heffner ${ }^{1}$, D. Q. Kellogg ${ }^{1}$, Kimberly Lellis-Dibble ${ }^{1}$, \\ James J. Opaluch $^{1}$, Candace Oviatt ${ }^{1}$, Anna Pfeiffer-Herbert ${ }^{1}$, Nicole Rohr ${ }^{1}$, Leslie Smith ${ }^{1}$, \\ Tiffany Smythe, Judith Swift ${ }^{1}$, and Nathan Vinhateiro ${ }^{1}$
}

\begin{abstract}
Lagoons are highly productive coastal features that provide a range of natural services that society values. Their setting within the coastal landscape leaves them especially vulnerable to profound physical, ecological, and associated societal disturbance from global climate change. Expected shifts in physical and ecological characteristics range from changes in flushing regime, freshwater inputs, and water chemistry to complete inundation and loss and the concomitant loss of natural and human communities. Therefore, managing coastal lagoons in the context of global climate change is critical. Although management approaches will vary depending on local conditions and cultural norms, all management scenarios will need to be nimble and to make full use of the spectrum of values through which society views these unique ecosystems. We propose that this spectrum includes pragmatic, scholarly, aesthetic, and tacit categories of value. Pragmatic values such as fishery or tourism revenue are most easily quantified and are therefore more likely to be considered in management strategies. In contrast, tacit values such as a sense of place are more difficult to quantify and therefore more likely to be left out of explicit management justifications. However, tacit values are the most influential to stakeholder involvement because they both derive from and shape individual experiences and beliefs. Tacit values underpin all categories of social values that we describe and can be expected to have a strong influence over human behavior. The articulation and inclusion of the full spectrum of values, especially tacit values, will facilitate and support nimble adaptive management of coastal lagoon ecosystems in the context of global climate change.
\end{abstract}

Key Words: climate change; coastal lagoons; ecosystems; social values

\section{INTRODUCTION}

Coastal lagoons support a range of natural services that are highly valued by society (Gönenç and Wolflin 2005), including fisheries productivity, storm protection, tourism, and others. We review how global climate change (GCC) will affect the physical structure, ecological characteristics, and social values associated with lagoons, with special emphasis on the U.S. Atlantic and Gulf of Mexico coasts.

This review follows similar ecosystem-specific assessments of the impacts of climate change in marine and coastal environments such as those of tropical coral reefs (Hoegh-Guldberg et al. 2007),
Amazonian forests (Malhi et al. 2008), and city ecosystems (Grimm et al. 2008). We summarize the key characteristics of lagoons in terms of their physical and ecological properties. We review the social values of lagoons and offer a nomenclature to frame discussion about these values. Although there is considerable literature on the physical and ecological dimensions of lagoons, there is much less literature focused on their economic and social values. Finally, we discuss how the physical, ecological, and social dimensions of lagoons are likely be impacted by GCC in the coming decades. Examples are presented from four geographically and culturally distinct lagoon ecosystems to illustrate the range of possible impacts of GCC. 
Climate change is only one of many sources of disturbance to lagoon ecosystems, and these disturbances occur concurrently at multiple temporal and spatial scales. Whereas some climate change stressors manifest slowly over decades and on regional and continental spatial scales, local, sitespecific stressors can occur rapidly and cause significant impacts to lagoons. Land-use change, freshwater withdrawal from ground and surface water sources, sedimentation, point and nonpoint water pollution, shoreline hardening, and overfishing are examples of anthropogenic stressors that can have profound and sudden impacts on coastal ecosystems (U.S. Environmental Protection Agency 2007, Khan 2007, Rodriguez et al. 2007, Bilkovic and Roggero 2008, Hollister et al. 2008a, $b$,). Interactions among the host of local stressors and GCC can also be important, but interactions are complex and highly site specific (e.g., Lloret et al. 2008). It is a major challenge for coastal researchers and managers to understand the interactions among these multiscale stressors (Vinebrooke et al. 2004). These important issues are beyond the scope of our review. Instead, we restricted our focus to examine long-term social and ecological effects of GCCinduced changes to lagoon ecosystems.

\section{LAGOON ECOSYSTEMS}

\section{Physical characteristics of lagoons}

A coastal lagoon is a "shallow coastal water body separated from the ocean by a barrier, connected at least intermittently to the ocean by one or more restricted inlets" (Kjerfve 1994; Fig. 1). For our purposes, we restricted our survey to lagoons separated from the ocean by a depositional land barrier, excluding coral reef lagoons. With a geographic range stretching from the arctic to the tropics (Nichols and Boon 1994), coastal lagoons are typically found along low-lying coastlines that have a tidal range of $<4 \mathrm{~m}$ (Martin and Dominguez 1994). Lagoons constitute $13 \%$ of coastal regions globally, range in area from $<0.01 \mathrm{~km}^{2}$ to $>10,000$ $\mathrm{km}^{2}$, and are typically $<5 \mathrm{~m}$ deep (Bird 1994, Kjerfve 1994).

Coastal lagoons are formed and maintained through sediment transport processes. Sediment carried by rivers, waves, currents, wind, and tides (Nichols and Boon 1994) accumulates in river and tidal deltas, on marshes and flats where submerged aquatic vegetation slows currents, and on washover fans. The process of sedimentation can eventually fill in lagoons (Nichols and Boon 1994). Lagoon barriers are constantly eroded by waves and wind, requiring continuous sediment deposition to maintain them (Bird 1994).

Water quantity and quality in a lagoon is influenced by the rate at which the lagoon loses or gains water from evaporation, precipitation, groundwater input, surface runoff, and exchange with the ocean (Allen et al. 1981). Lagoon-ocean exchange is driven by tides and wave action (Zimmerman 1981) and is often the largest component of lagoon water balance (Smith 1994). Heat is also lost and gained through exchange with the atmosphere, sediment, and ocean (Smith 1994).

The flushing rate, i.e., the rate at which water enters, circulates through, and exits the lagoon, is a fundamental physical property and controls the retention time of waterborne constituents. Lagoons tend to have low flushing rates because of restricted exchange with the ocean, contributing to high primary productivity and potentially high pollutant concentrations (Spaulding 1994). Determinants of the flushing rate include the size and shape of the lagoon, the level of connectivity with the ocean, tidal range, and freshwater flow (Phleger 1981).

\section{Ecological characteristics of lagoons}

Coastal lagoons are highly productive ecosystems. They contribute to the overall productivity of coastal waters by supporting a variety of habitats, including salt marshes, seagrasses, and mangroves. They also provide essential habitat for many fish and shellfish species. For example, seagrass beds are a common feature of soft-substrate lagoons on the Atlantic coast. Where seagrass beds occur, Zostera marina (eelgrass) is the most dominant species from Maine to the Carolinas, whereas Thalassia testudinalinum (turtle grass) is the most dominant species south of the Carolinas (Bertness 2007). Such beds play an important role in influencing the shape and stability of the shoreline, regulating dissolved oxygen (Nixon and Oviatt 1972), and filtering suspended matter (Bertness 2007). They can enhance the biodiversity of a lagoon by providing a physical refuge from predation and also serve as nursery and feeding habitats for a variety of organisms (Heck and 
Fig. 1. Idealized coastal lagoon showing important landforms and characteristics.

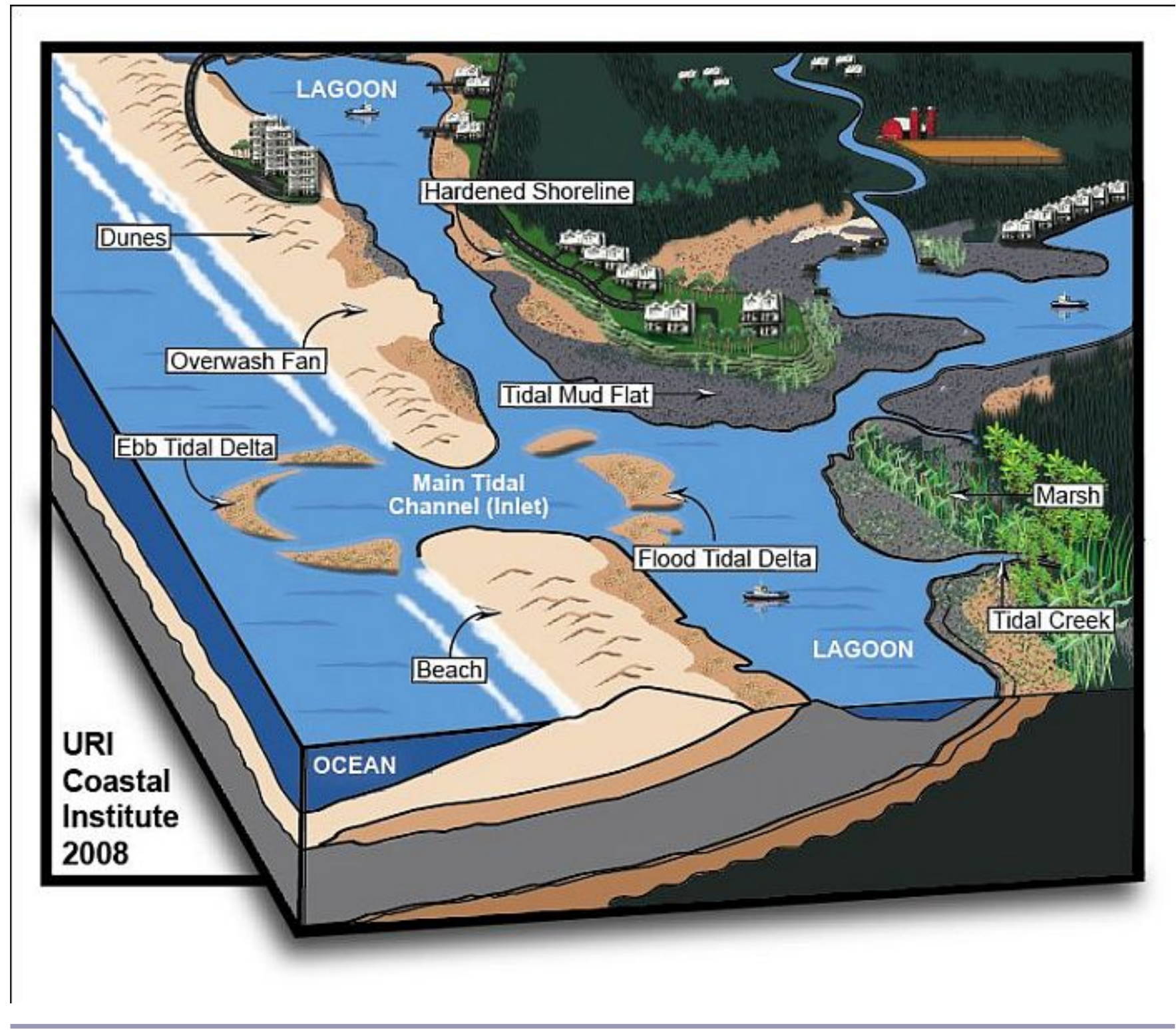

Thoman 1984, Harris et al. 2004). On the Atlantic coast, salt marshes are one of the most prevalent habitats in lagoons (Bertness 2007) and are one of the most productive natural vascular plant communities in the world (Whittaker 1975).

Because of their relatively low flushing rates, coastal lagoons are favorable habitats for primary producers (phytoplankton and aquatic plants). Nutrients are transported to lagoons from surface water and groundwater flows and through exchange with the ocean. Because nutrient availability often limits primary productivity, coastal lagoons can foster high rates of primary production, thereby supporting high rates of secondary production compared to other aquatic ecosystems (Nixon 1982, 1995). However, primary production that exceeds the demands of consumers can lead to eutrophication (Valiela et al. 1992). Eutrophication is characterized by excessive phytoplankton and 
macroalgal blooms and subsequent hypoxia, reduced light penetration (McGlathery 2001, Anderson et al. 2002), stress and die-offs of marine organisms, loss of seagrass beds, changes in food web interactions and community structure, and loss of biodiversity (National Research Council 2000).

\section{Social value characteristics of lagoons}

Lagoons and their associated ecosystems are highly valued by society. However, the concept of value has different meanings in different disciplines. Among philosophers, there is debate over whether natural systems possess an intrinsic value of their own that lies outside human determination (Taylor 1986, Rolston 1994, Williams 1994). These are complex philosophical issues that cannot be resolved here; we therefore focus only on manifestations of social values of lagoons.

Because manifestations of social values differ greatly, we organize them into four general categories: pragmatic, scholarly, inspirational, and tacit (Fig. 2). We use the term "social values" to represent a synthesis of these categories. The placement of a manifestation of value within one category does not preclude its effect on or migration into another category. For example, although the economic engine of tourism might manifest itself as a pragmatic form of social value, the appeal of a tourist destination depends on its power to attract individuals, which in turn depends upon inspirational and tacit manifestations of social value such as dramatic scenery, pleasant swimming beaches, or shops selling mementos that capture the highlights of the tourist experience. Thus, the spectrum of four categories is intended to be a practical device for discussing specific manifestations of social value in relation to coastal lagoons.

Pragmatic values are the most tangible manifestations of value and are commonly referred to as "use" values in the policy, management, and economic literature (Cicin-Sain and Knecht 1998). These values reflect the commercial, recreational, and tourism uses of lagoons. Pragmatic values also include ecosystem services that indirectly support human uses. For example, salt marshes provide nursery habitat for juvenile fish that support commercial fisheries and also protect developed shorelines by reducing the impact of severe storms.
Scholarly values are embodied in activities that seek to extend our knowledge about lagoon systems and include scientific inquiry and historical study. Scholarly manifestations often contribute to pragmatic values. For example, a better understanding of lagoons can improve management, potentially increasing commercial fisheries' catch and tourism revenues. Society also values knowledge for its own sake (Hume 1999). Thus, basic research on ecological, historical, or geological dimensions of lagoon systems provides scholarly value.

Inspirational values are ascribed to creatively productive activities that include photography and landscape painting, as well as settings for films, literature, songs, and other artistic expressions. These artistic creations encompass both personal aesthetic response to natural systems (tacit values) and profit from the sale of resulting artworks (pragmatic value).

Tacit values (Naukkarinen 1998) refer generally to unspoken values and include the enjoyment of scenery, the sounds of waves and shorebirds, and other sensory landscape features. Tacit values also encompass less tangible perceptions such as having a sense of place. In addition, society may ascribe economic existence value (e.g., Krutilla 1967) to an ecosystem irrespective of whether society uses it in any manner (Fig. 3).

Some manifestations of value are more easily quantified than others (National Research Council 2005), increasing the chance of their being considered and weighted more heavily in coastal management. Tacit values present the biggest challenge to quantification because they are implicit and difficult to articulate and therefore are often missing from data sets or surveys. However, they frequently manifest themselves indirectly through market transactions or other economic indicators. Small seaside cottages on stilts, for example, sit alongside lagoons or barrier islands and command million dollar price tags. Such prices reflect the powerful effect of tacit values on coastal waterfront property. The strength of tacit values is clearly evident when people choose to live in areas of high environmental risk such as low-lying coastal landscapes to benefit from aesthetic amenities or the cultural sense of place that these landscapes provide (Couzin 2008). 
Fig. 2. Social values for lagoons and other natural systems.

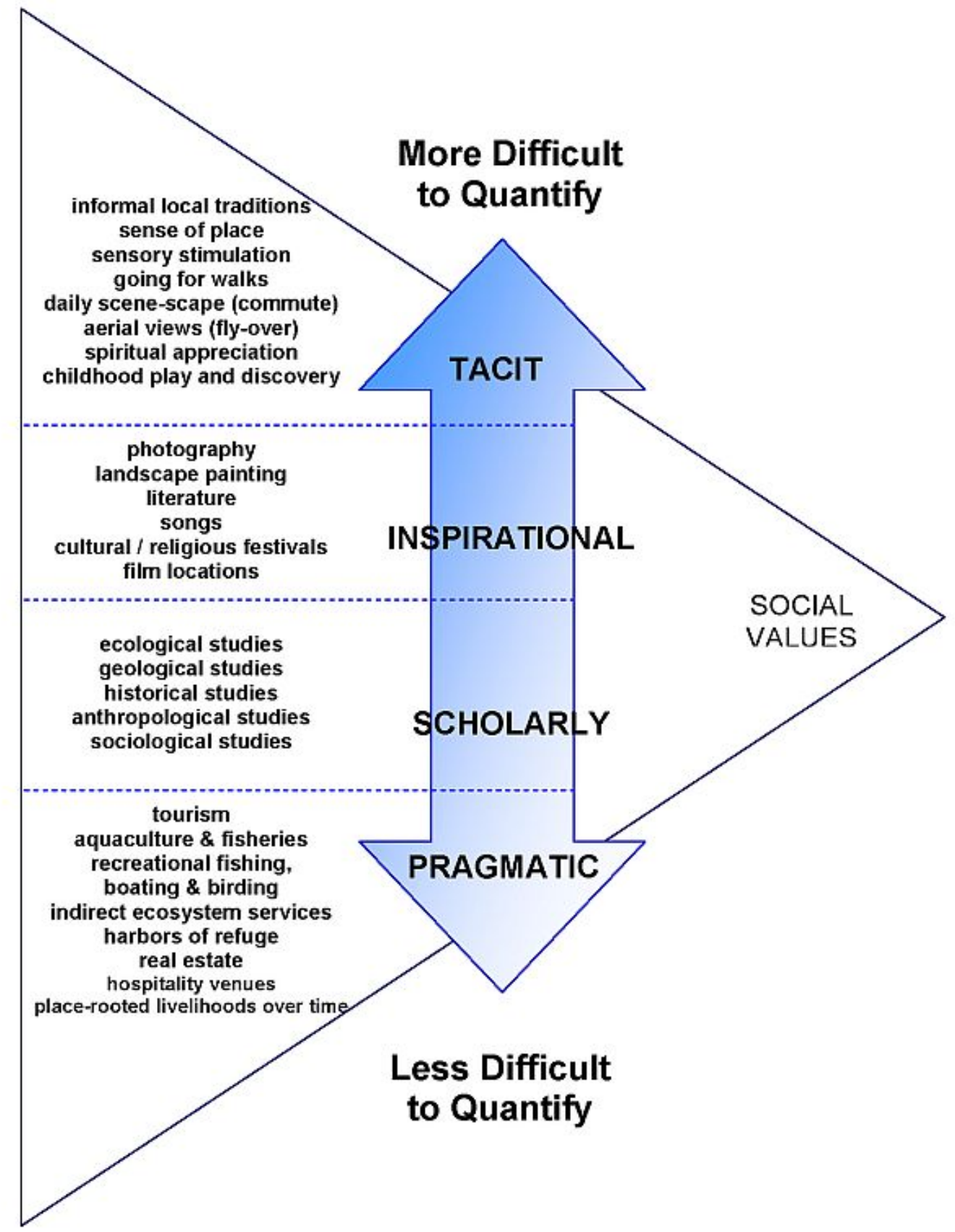


Fig. 3. Tacit values capture a sense of place. Point Judith Pond, Rhode Island, USA.

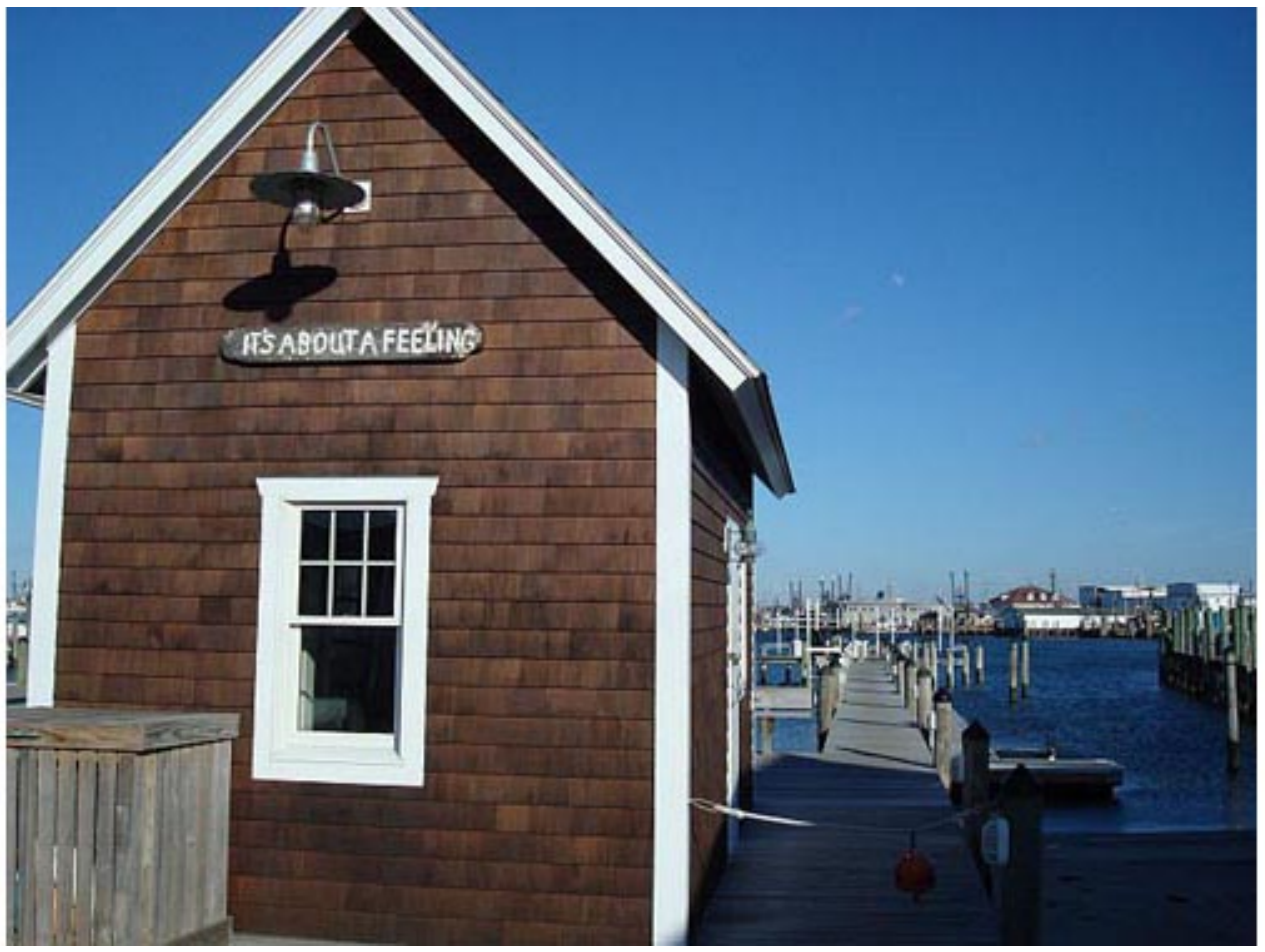

Inspirational values often yield a quantifiable product with high market value such as a painting, book, or film, or a popular cultural festival. Each example begins with inspirational value, but the end result can be estimated through pragmatic and scholarly means (such as tourism or cinematic criticism), thereby demonstrating the migration of inspirational values into the scholarly and pragmatic.

Social scientists have developed both qualitative and quantitative tools for incorporating all categories of value into management actions. For example, one qualitative approach developed by social scientists is the charrette, which includes unstructured discussions in public meetings (Berke et al. 2006). Quantitative means of measuring value, by contrast, include the revealed preference approaches developed by economists (Freeman 2003). Although it is beyond the scope of our review to discuss these and other methods in detail, we briefly summarize some methods in Table 1, with additional details provided in Appendix 1. Despite this array of tools, the central challenge remains for coastal managers to incorporate the full spectrum of values, even those that are difficult to quantify.

\section{CLIMATE CHANGE IMPACTS ON LAGOON ECOSYSTEMS}

Sea level, temperature, precipitation, and storminess are expected to change significantly with GCC and to impact coastal lagoons directly (Table 2). Indirect impacts such as ocean acidification are important, but there is great uncertainty regarding potential effects on coastal and marine ecosystems (Royal Society 2005); we therefore focus on direct impacts in our review. Although both precipitation and storminess can be severe during certain weather events (e.g., hurricanes, nor'easters), we treat them as separate aspects of climate because they influence lagoons in different ways. Here, we summarize the current state of knowledge regarding these climate change variables and describe how 
Table 1. Standard methods of quantifying values. See Appendix 1 for additional information.

\begin{tabular}{|c|c|c|}
\hline Method & Description & Discipline \\
\hline $\begin{array}{l}\text { Visual preference survey, } \\
\text { visualization, visual impact } \\
\text { assessment }\end{array}$ & $\begin{array}{l}\text { Measures tacit manifestations of aesthetic values such as } \\
\text { individual preferences for landscapes, architecture, or other } \\
\text { features. Provides assessments that are primarily qualitative in } \\
\text { nature. }\end{array}$ & $\begin{array}{l}\text { Community planning, } \\
\text { landscape architecture }\end{array}$ \\
\hline Charrette & $\begin{array}{l}\text { Elicits stakeholder input on a planning process or design using } \\
\text { intensive meetings. Incorporates all categories of value into policy } \\
\text { without providing explicit value measures. Is primarily } \\
\text { qualitative. }\end{array}$ & Policy, planning \\
\hline Revealed preference tools & $\begin{array}{l}\text { Infers people's values from actual choices made, typically in a } \\
\text { market context. Examples include hedonic pricing and travel cost } \\
\text { methods. Provides quantitative assessments of value, typically in } \\
\text { dollar terms. }\end{array}$ & Economics \\
\hline Stated preference survey & $\begin{array}{l}\text { Infers tacit manifestations of value through people's responses to } \\
\text { hypothetical survey questions. Examples include contingent } \\
\text { valuation and contingent choice. Provides primarily quantitative } \\
\text { assessments of value, often in dollar terms. }\end{array}$ & Economics \\
\hline Interview techniques & $\begin{array}{l}\text { Ranges from informal discussion to structured surveys. Elicits } \\
\text { values through people's responses. Provides quantitative or } \\
\text { qualitative results, sometimes in dollar terms. }\end{array}$ & $\begin{array}{l}\text { Sociology, psychology, } \\
\text { economics, decision } \\
\text { science }\end{array}$ \\
\hline Social/civic valuation & $\begin{array}{l}\text { Measures values that groups place on amenities, either through } \\
\text { actual decisions made or through hypothetical questions posed to } \\
\text { groups. Examples include results of public referendum and focus } \\
\text { groups. Provides qualitative or quantitative results, sometimes in } \\
\text { dollar terms. }\end{array}$ & Policy, planning \\
\hline
\end{tabular}

they will likely affect the physical structure, ecological properties, and social values associated with lagoons.

\section{Sea level}

The magnitude, rate, and effects of relative sea level increase will vary regionally because of differences in subsidence (resulting from sediment loading, groundwater withdrawal, or oil extraction), tectonic uplift, isostatic rebound, and the compaction of muddy soils. Reconstructed sea level increase estimates using tidal gauge data from 1870 to 2004 indicate that the historical average $( \pm 95 \%$ confidence limits) rate of sea level increase was 1.7 $\pm 0.3 \mathrm{~mm} / \mathrm{yr}$, with significant acceleration measured at $0.013 \pm 0.006 \mathrm{~mm} / \mathrm{yr}$ (Church and White 2006). Satellite observations, however, show that since 1993, the sea level has been increasing at a rate of approximately $3 \mathrm{~mm} / \mathrm{yr}$, which is significantly higher than the average over the previous halfcentury (Cazenave and Nerem 2004). Global sea level increase in the 20th century measured approximately $170 \mathrm{~mm}$ (Bindoff et al. 2007) and is expected to increase exponentially in the $21 \mathrm{st}$ century as air temperatures continue to increase (Rahmstorf 2007). By 2050, the sea level is expected to have risen approximately $60-330 \mathrm{~mm}$ (Union of Concerned Scientists 2006), and by 2100, is expected to have risen by $50-1400 \mathrm{~mm}$ above the 1990 level (Rahmstorf 2007), with the potential to increase $>5000 \mathrm{~mm}$ within the next millennium (Overpeck et al. 2006). 
Table 2. Direct effects of projected global climate change factors on processes and physical properties of coastal lagoons.

\begin{tabular}{|c|c|c|c|c|}
\hline \multirow[b]{2}{*}{$\begin{array}{l}\text { Processes and } \\
\text { physical properties }\end{array}$} & \multicolumn{4}{|c|}{ Climate change factor } \\
\hline & Sea level & $\begin{array}{l}\text { Air and open ocean } \\
\text { temperatures }\end{array}$ & Precipitation & Storms \\
\hline \multicolumn{5}{|l|}{ Processes } \\
\hline $\begin{array}{l}\text { Barrier-lagoon } \\
\text { migration }\end{array}$ & $\begin{array}{l}\text { Erosion and shoreward } \\
\text { migration of barrier } \\
\text { islands }{ }^{1,2,3}\end{array}$ & & & $\begin{array}{l}\text { Rapid sediment } \\
\text { redistribution }\end{array}$ \\
\hline Flushing rate & $\begin{array}{l}\text { Increased flushing due } \\
\text { to barrier breaching }\end{array}$ & & $\begin{array}{l}\text { Variability in freshwater } \\
\text { input increases } \\
\text { variability in flushing }\end{array}$ & $\begin{array}{l}\text { Increased flushing due } \\
\text { to barrier breaching }\end{array}$ \\
\hline Sedimentation & & & $\begin{array}{l}\text { Sediment flux inversely } \\
\text { related to } \\
\text { precipitation }^{15,17,18}\end{array}$ & $\begin{array}{l}\text { Increased sediment } \\
\text { transport }\end{array}$ \\
\hline \multicolumn{5}{|l|}{ Physical properties } \\
\hline $\begin{array}{l}\text { Lagoon water } \\
\text { temperature }\end{array}$ & & $\begin{array}{l}\text { Temperature } \\
\text { increase amplified in } \\
\text { shallow systems }\end{array}$ & & \\
\hline Salinity & $\begin{array}{l}\text { Change in salinity } \\
\text { through inundation }\end{array}$ & & $\begin{array}{l}\text { Salinity inversely related } \\
\text { to freshwater input }\end{array}$ & $\begin{array}{l}\text { Higher salinity due to } \\
\text { increased breaching and } \\
\text { wash-over events }\end{array}$ \\
\hline Nutrients & & & $\begin{array}{l}\text { Higher nutrient input } \\
\text { through overall } \\
\text { increased terrestrial } \\
\text { runoff }^{20,21}\end{array}$ & \\
\hline Light penetration & & & $\begin{array}{l}\text { Increased suspended } \\
\text { solids during freshwater } \\
\text { runoff events }\end{array}$ & \\
\hline Oxygen & & $\begin{array}{l}\text { Decreased oxygen } \\
\text { solubility with } \\
\text { increased } \\
\text { temperature }^{23,24}\end{array}$ & $\begin{array}{l}\text { Lower dissolved oxygen } \\
\text { with increased } \\
\text { stratification }^{18,20}\end{array}$ & \\
\hline
\end{tabular}

1: Brunn 1962, 2: Titus 1990, 3: Pilkey and Cooper 2004, 4: Boothroyd et al. 1985, 5: Fenster and Dolan 1993, 6: Morton and Sallenger 2003, 7: Bird 1993, 8: Oliveira et al. 2006, 9: Paerl et al. 2006, 10:

Trenberth et al. 2007, 11: Kjerfve and Magill 1989, 12: Fritz et al. 2007, 13: Harley et al. 2006, 14:

Nixon et al. 2004, 15: Scavia et al. 2002, 16: Intergovernmental Panel on Climate Change 2007, 17:

Michener et al. 1997, 18: Najjar et al. 2000, 19: Chabreck and Palmisano 1973, 20: Justic et al. 1996, 21: Rogers and McCarty 2000, 22: Steward et al. 2006, 23: Pilson 1998, 24: Bopp et al. 2002. 
Accelerated sea level increase is a particular threat to low-lying, shallow-gradient coastal ecosystems. Most barrier-lagoon systems respond naturally to sea level increase by migrating landward along undeveloped shorelines with gentle slopes (Hayes 2005); the retreating shore face profile can remain essentially unchanged as the shoreline retreats landward and upward in response to moderate sea level increases (Bruun 1962). However, with accelerated sea level increase, landward retreat of barriers may not be rapid enough to prevent inundation (Zhang et al. 2004). Hardened shorelines on developed coastlines impede this natural migration and increase the vulnerability of coastal structures to inundation and storm damage (Titus 1998).

As lagoon barriers retreat landward, accelerated sea level increase will lead to steeper and narrower barrier profiles, shortening the length of existing inlets (Bird 1994) and increasing the rate of exchange with the ocean. This will likely increase the barriers' vulnerability to breaching and the lagoons' flushing rates (Zimmerman 1981). As lagoons are inundated by seawater, salinity will increase, possibly altering the species composition (Bird 1993, Mackenzie et al. 2007). If a lagoon barrier persists, a sea level increase will also reduce light penetration to submerged aquatic vegetation, reducing the photosynthetic potential of these primary producers and changing the nutrient dynamics such that lagoons may be more susceptible to eutrophication (Lloret et al. 2008).

\section{Temperature}

In the last $100 \mathrm{yr}$, global air temperature has increased by $0.76^{\circ} \mathrm{C}$ and is expected to increase by an additional $1.1-6.4^{\circ} \mathrm{C}$ by 2100 (Intergovernmental Panel on Climate Change 2007). Temperature increases will vary regionally and will be modulated by natural climate variation (e.g., Smith et al. 2007, Keenlyside et al. 2008). The greatest warming is expected to occur at high latitudes in winter (Intergovernmental Panel on Climate Change 2007, Serreze et al. 2007).

Changes in air temperature strongly influence the water temperature of slow-moving, shallow water bodies such as coastal lagoons (Turner 2003). The temperature of the world's oceans has increased, on average, by $0.3{ }^{\circ} \mathrm{C}$ (Intergovernmental Panel on
Climate Change 2007) and is likely to continue to increase through the next century. Because air temperatures increase more quickly over land than over oceans, coastal water temperatures are also likely to increase more rapidly (Harley et al. 2006). For example, in Narragansett Bay, Rhode Island (median depth $6.4 \mathrm{~m}$; Boothroyd and August 2008), the annual average surface water temperature has increased by $1.1^{\circ} \mathrm{C}$ in the past $50 \mathrm{yr}$ (Nixon et al. 2003). This rate of increase is approximately four times greater than that of the ocean. Although we are not aware of published, long-term data for water temperature in coastal lagoons, the shallow nature and low flushing rates of coastal lagoons indicate that water temperatures in lagoons will increase even more rapidly than water temperatures in open estuaries.

Water temperature in turn influences dissolved oxygen concentrations, as well as the physiology of lagoon organisms, species' ranges, and patterns of migration (Woodward 1987, Turner 2003). Many marine species live near their threshold of thermal tolerance (Tomanek and Somero 1999), at which even small changes in temperature can have large impacts on their viability. In addition, these ecosystems are more susceptible to increases in the colonization of invasive species that may thrive in warmer waters (Stachowicz et al. 2002). As lagoon temperatures increase, dissolved oxygen concentrations are likely to decrease (Bopp et al. 2002, Joos et al. 2003), especially as seasonal stratification of the water column isolates oxygen-depleted deeper waters from oxygen-rich surface waters (Bopp et al. 2002, Joos et al. 2003). Reduced dissolved oxygen adversely affects aerobic biota, with benthic communities expected to be the most severely stressed. In lagoons with high flushing rates, the influx of ocean water will interrupt stratification, causing the water column to mix. In restricted lagoons with low flushing rates and high nutrient inputs, temperature increases will increase the probability and severity of hypoxic events (D'Avanzo and Kremer 1994). Chronic hypoxia in coastal waters has been linked to long-term changes in benthic community structure characterized by a persistent shift in species composition to more hypoxia-tolerant species and an overall decrease in species diversity (Conley et al. 2007).

The timing (phenology) of lagoon processes will also be affected by temperature increases. For example, changes in air temperature have affected 
the timing and route of migrating birds that traditionally stop over at coastal lagoons (Gatter 1992). Developmental and reproductive timing in shellfish as evidenced by early gonad maturation and spawning in bay scallops is associated with higher water temperatures (Sastry 1963). Changes in plankton phenology have also been observed, with zooplankton becoming active earlier in the year following relatively warm winters (Edwards and Richardson 2004). Increased grazing of phytoplankton by zooplankton has been observed and may partially explain declines in phytoplankton abundance associated with warmer temperatures (Oviatt 2004). Warmer temperatures are also thought to contribute to observed declines in seagrass abundance (Blintz et al. 2003).

\section{Precipitation}

There is general agreement that there will be changes in precipitation intensity, timing, volume, and form (snow or rain) because of GCC (Meehl et al. 2007). Estimates of the magnitude and timing of changes in precipitation patterns along the U.S. Atlantic and Gulf coasts are variable, reflecting the high level of uncertainty associated with these predictions (Graham et al. 2007). Although predictions agree that there will be an increase in extreme rainfall events and drought-flood cycles (Scavia et al. 2002, Committee on Environment and Natural Resources 2008), disagreement persists regarding the direction of expected changes in other components of the water cycle such as stream flow (timing and volume), evapotranspiration, soil moisture, and groundwater storage resulting from complex interactions between and among factors such as air temperature and seasonal timing of precipitation events.

Regional changes in precipitation patterns can have important effects on the physical and ecological characteristics of coastal lagoons through the alteration of freshwater inputs and associated changes in salinity and dissolved oxygen concentrations (Milly et al. 2005). Intense precipitation events would increase short-term freshwater inputs (Paerl et al. 2006) while locally decreasing salinity (Michener et al. 1997). Conversely, lower precipitation would reduce freshwater inputs and potentially result in higher salinity (Valiela 1995). Salinity would also be affected by changes in flushing rate, which may counteract the changes in freshwater inputs.
Increased freshwater inputs can also contribute to the stratification of deeper lagoons (Justic et al. 1996), increasing the risk of hypoxia in bottom waters (Bopp et al. 2002, Joos et al. 2003). The expected increase in the variability and intensity of precipitation events is therefore expected to produce increased variability, both spatially and temporally, in salinity and dissolved oxygen concentrations in coastal lagoons.

Other effects of increased surface water inputs include the increased delivery of sediment and nutrients to lagoons (Orpin et al. 1999). Increased nutrient inputs may accelerate the eutrophication of lagoons, especially those with low flushing rates (McComb 1995, Wazniak et al. 2007). As with sea level increases, increased turbidity will reduce light penetration and the photosynthetic activity of submerged aquatic vegetation, compounding the risk of eutrophication as nutrient dynamics are further altered (Lloret et al. 2008). In addition, reduced light penetration can inhibit the feeding ability of visual predators (Howick and O'Brien 1983, Fiksen et al. 2002, Horppila et al. 2004).

\section{Storms}

Storms affect lagoons through overwash events and by erosion from wind and waves. There is disagreement among predictions concerning the extent and magnitude of changes in storminess with GCC. Evidence of an increase in intense tropical cyclone activity in the North Atlantic over the past $40 \mathrm{yr}$ (Meehl et al. 2007, Trenberth et al. 2007) supports predictions that the frequency (Holland and Webster 2007, Mann et al. 2007) and intensity (Emanuel 2005, Webster et al. 2005) of extreme weather events have been increasing and will continue to increase with warmer global temperatures. However, these predictions have been challenged by suggestions that the apparent trend in increasing storm frequency is an artifact of improved monitoring (Landsea 2007) and by predictions that increased vertical wind shear could dampen the effects of increasing hurricane intensity (Vecchi and Soden 2007). Meehl et al. (2007) suggest that a warmer climate will increase the overall intensity of tropical cyclones and, whereas the number of storms is expected to decrease globally by the end of the 21 st century, the number of storms in the North Atlantic could increase by as much as 34\% during this period (Oouchi et al. 2006). 
The consequences of sea level increase become acute during storm events because sea level increase and storms interact to erode barriers and produce high storm surges, rapidly redistributing barrier sediment (Fenster and Dolan 1993). During periods of high storm surge, water moves rapidly over the barrier in a process called overwash, which delivers sediment eroded from the front of the barrier onto the back barrier flat and into the lagoon (Wilby et al. 1939, Leatherman 1981). Increased storm intensity will likely cause more frequent breaches of barrier islands (Morton and Sallenger 2003), which in turn will increase the rate of exchange with the ocean and consequently the flushing rate and salinity of lagoons (Bird 1994, Smith 1994).

\section{CLIMATE CHANGE IMPACTS ON SOCIAL VALUES OF LAGOONS}

The combined effects of increased temperature, sea level, and storminess and the variability in weather patterns will likely stress human communities that value the presence of particular lagoons. Lagoons are valued for many reasons: as ecosystems that support an abundance of species on which livelihoods depend (pragmatic), as sites of historical tradition (scholarly), as incentive for creative pursuits (inspirational), and as a source of a sense of place (tacit).

When faced with GCC stressors, society may take actions to reduce impacts. However, these actions may also have unintended consequences, creating a feedback cycle that can have long-term negative consequences. For example, people have historically reacted to coastal erosion by hardening shorelines with sea walls or riprap. Hardened shorelines may protect coastal structures in the short term, but they can exacerbate erosion elsewhere by reducing sources of sand to replenish shorelines downcoast.

To explore how particular social structures and physical and ecological characteristics are likely to be impacted by GCC in the coming decades, we examined four specific lagoon systems on the Atlantic and Gulf coasts: the Gulf Coast of Louisiana, the salt ponds of Rhode Island, the Outer Banks and Lowcountry of the Carolinas, and Jamaica Bay, New York (Fig. 4). Table 3 provides a brief summary of the socio-geographic settings of the four lagoon systems, as well as key GCC factors and some likely ecosystem impacts. These lagoons were selected to cover a broad geographic range and include systems with distinct human development patterns and a variety of social values.

\section{Gulf Coast of Louisiana}

Coastal Louisiana is a vast rural complex of lagoons, bayous, canals, channels, and small embayments that are particularly vulnerable to sea level increase (Burkett et al. 2003). These coastal lands are disappearing at a rate of up to $100 \mathrm{~km}^{2} / \mathrm{yr}$ because of the combined effects of sea level increase, hurricanes, subsidence, and erosion (United States Geological Survey National Wetlands Research Center, LaCoast: http://www.lacoast.gov). Without abatement, an additional $3200 \mathrm{~km}^{2}$ of wetlands are predicted to be inundated by 2040 , advancing the Louisiana shoreline inland by as much as $53 \mathrm{~km}$ in some areas. These losses are caused in part by human actions in response to flooding threats, including increased channelization of the Mississippi River with levees, which has controlled flooding, but has also cut off sediment supply to delta wetlands and has diverted sediments to deep waters off the continental shelf. This has exacerbated the effects of sea level increase with significant negative impacts on barrier islands and wetlands (Dean 2006).

Coastal Louisiana's lagoons and wetlands are spawning, nursery, and fishing grounds for many important fisheries. For example, shrimp landings in Louisiana constitute roughly $30 \%$ of the ex-vessel value of the national shrimp catch (National Marine Fisheries Service annual commercial landing statistics: http://www.st.nmfs.noaa.gov/st1/commercial/ landings/annual landings.html). Sea level increase will intensify the loss of critical salt marsh habitat (Mendelssohn and McKee 1988, Wilsey et al. 1992, Ogburn and Alber 2006). Flooding from sea level increase will increase salinity and may stress juvenile shrimp that mature in low-salinity estuarine waters (Gunter 1961). The shrimp fishery has significant pragmatic value in this region and is also a unique way of life that embodies inspirational and tacit values.

Louisiana's Barataria Bay (Fig. 4) sustains rich biodiversity by providing not only important habitat for waterfowl, shrimp, and finfish, but also serving as homeland to several cultures, creating a unique sociological phenomenon in which highly diverse 
Fig. 4. Locations of the four lagoons used in the case studies of ecological and social values. Photograph inserts used with permission.

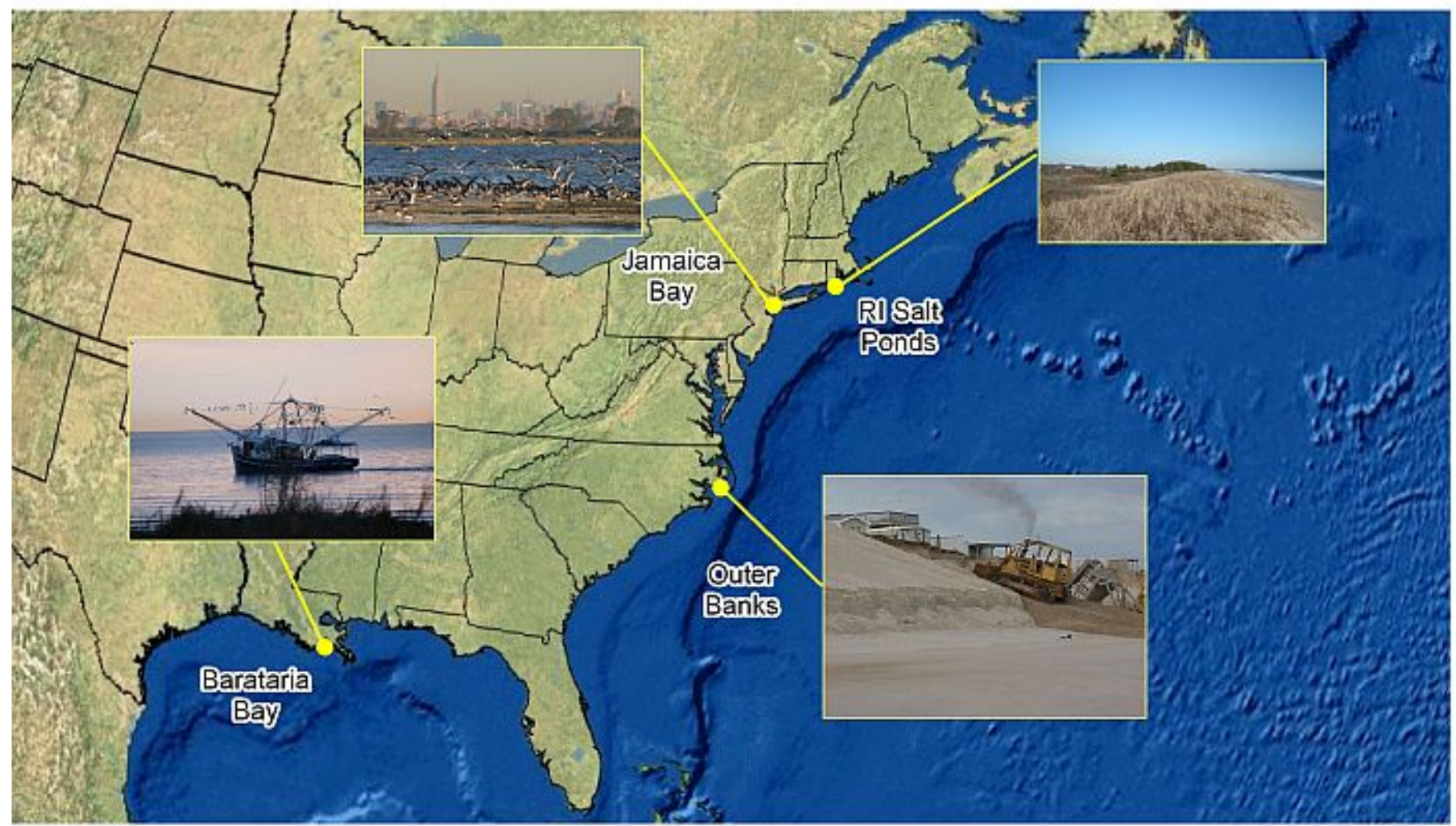

communities (Houma, Cajun, Creole, AfricanAmerican, Vietnamese, and Canary Island Spaniards) share a single ecosystem (Gomez 1998, Tidwell 2003, Gramling and Hagelman 2005). These cultures share a high degree of poverty or economic uncertainty, leaving them more vulnerable to the effects of GCC (Rosenzweig et al. 2007).

Moreover, the inundation of Louisiana's coastal lagoons increases the vulnerability of New Orleans to flooding, risking the loss of one of the world's iconic cities and the living culture that produced jazz, one of America's indigenous art forms (Gushee 1994). With the loss of these coastal lagoons, a powerful experience of place is also lost, existing only in nostalgic representations preserved in artworks such as those of Colette Pope Heldner (Fig. 5A) and John James Audubon or the writings of James Lee Burke.

\section{Salt ponds of Rhode Island}

The string of lagoons along the south shore of Rhode Island are known locally as salt ponds and figure prominently in a complex landscape of highly developed residential areas, commercial waterfronts, agricultural areas, and uninhabited protected refuges (Fig. 3). These lagoons have historically played an important role in Native American culture, and contemporary human uses include commercial and recreational fishing, boating, 
Table 3. Direct connections between social, global climate change (GCC), and ecological impacts in four coastal lagoons.

\begin{tabular}{|c|c|c|c|c|}
\hline \multirow[b]{2}{*}{ Characteristic } & \multicolumn{4}{|c|}{ Lagoon system } \\
\hline & Barataria Bay & Rhode Island salt ponds & $\begin{array}{l}\text { Carolina Outer Banks } \\
\text { and Lowcounty }\end{array}$ & Jamaica Bay \\
\hline
\end{tabular}

Geography/

social

Anticipated

GCC impacts

Ecological impacts (examples)
Barataria Bay lagoon systems: these largely rural settings are replete with small settlements populated by marsh dwellers who live as part and nature refuges ${ }^{2}$ of the landscape ${ }^{1}$
A "string of pearls" of shallow coastal salt ponds representing a range of lagoon settings: tourism sprawl, exurban,

\section{A strand of islands and barrier beaches rich in history from the traditionally accepted founding of the first colony in America to the influence of the slave trade and the Civil War. These barrier islands also have a history of extreme vulnerability to hurricanes $^{3}$}

Air temperature: Predicted to increase by $1.1-2.2^{\circ} \mathrm{C}$ by $2100^{5}$ $10 \%$ in summer and fall ${ }^{11}$ leads to $1-3$ parts per trillion decrease in salinity $^{12}$

Sea level: Rate of increase is faster than marsh accretion rates ${ }^{19}$ Storms: Vulnerable to tropical storms and hurricanes, which cause devastation of marsh grasses, wash-over fans, and erosion from shallow areas ${ }^{20,21}$

Increased salinity from sea level increase will result in the loss of nursery and mating habitat, affecting juvenile penaeid shrimp and blue crabs, both of which are commercially important. $^{26,27}$

Conversely, the increased marsh subsidence will benefit shrimp by increasing the amount of time the marsh surface is available $^{28}$
Air temperature:

Predicted to increase by $1.9-6.9^{\circ} \mathrm{C}$ by $2100^{6}$

increase ${ }^{13}$ will increase erosion of barrier beaches, landward migration of barriers, ${ }^{14}$ and extensive loss of coastal wetlands ${ }^{13}$

Storms: High degree of shoreline change due to the narrow and low profile of barrier beaches $^{13}$

Precipitation: High flow to estuaries with large watersheds are most common $^{7}$

Sea level: The relative increase is between 3 and $4 \mathrm{~mm} / \mathrm{yr}^{15,16,17,18}$

Storms: Vulnerable to tropical storms and hurricanes, which accelerate inlet formation, wash-over fans, and inundation ${ }^{15,22,23,24,25}$ increased water depth and salinity from sea level increase will affect seagrass habitats. ${ }^{29}$

Shifts in species, species distribution, and abundance of seagrasses may occur, affecting local species that are dependent on seagrass habitat such as juvenile flounder $^{29}$

Migratory birds that depend on barrier beaches will experience the loss of habitat. ${ }^{30}$ Low oxygen conditions resulting from increased eutrophication will have negative impacts on vulnerable species such as striped bass ${ }^{30}$
Temperature stress and
A lagoon located within Gateway National Park in the outer boroughs of New York City (specifically, Brooklyn and Queens), directly adjacent to John F. Kennedy International Airport. The park attracts 6 million visitors each year $^{4}$

Storms: More frequent storm surges and greater wave action superimposed on sea level increase will exacerbate marsh erosion $^{8,9,10}$

Without adequate sediment supply and with increased erosion, populations of horseshoe crabs will be affected by the loss of suitable shoreline for breeding habitat. ${ }^{31}$ Decreases in food supply from decreases in horseshoe crab eggs and in salt marsh habitat will negatively affect migrating shorebirds ${ }^{31,32}$ 
1: Gramling and Hagelman 2004, 2: Lee 1980, 3: Bailey 1999, 4: Hoffmann 2006, 5: Ning and Abdollahi 2003, 6: Frumhoff et al. 2007, 7: Dame et al. 2000, 8: Gornitz et al. 2002, 9: Hartig et al. 2002, 10: Rosenzweig et al. 2007, 11: Turner 2003, 12: Swenson 2003, 13: Donnelly and Bertness 2001, 14: Boothroyd et al. 1985, 15: Dame et al. 2000, 16: Leatherman et al. 2000, 17: Simas et al. 2001, 18: Titus and Richman 2001, 19: Hatton et al. 1983, 20: Rodney 1970, 21: Day et al. 2007, 22: Fenster and Dolan 1994, 23: Zhang et al. 2004, 24: Paerl et al. 2005, 25: Greening et al. 2006, 26: Darnell 1959; 27: Gunter 1961, 28: Rozas and Reed 1993, 29: Short and Neckles 1999, 30: Najjar et al. 2000, 31: Botton et al. 2006, 32: Brown et al. 2001.

birding, surfing, and photography (Fig. 4). Local communities depend upon the fishing industry, and these lagoons provide habitat for a variety of commercially important shellfish and finfish.

Rhode Island's salt ponds are currently under heavy pressure from residential development. Past construction of stabilized breachways dramatically altered the salinity in many of these lagoons, shifting the lagoon community from brackish species (alewives, smelt, oysters) to species that thrive in more saline conditions (e.g., quahogs, winter flounder; Lee 1980) and are viewed as pragmatically valuable to local communities. Sea level increase will likely increase the lagoons' salinity through breaching of barriers, promoting another shift in species composition. Temperature increases and reduced water clarity will be detrimental to eelgrass beds and will impede restoration efforts to increase the areal extent of these submerged aquatic vegetation habitats (Short and Neckles 1999). Storminess and sea level increase are of particular concern because hardedged coastal development (i.e., permanent structures) restricts the migration of barrier and headland shorelines (Lee 1980). Pragmatic values will be impacted through property loss (Donnelly and Bertness 2001) as shorelines continue to shift because of sea level increase and increased storm intensity. Impacts are compounded because real estate on lagoons is some of the most expensive property in these coastal communities. The means for the continued survival of the salt ponds is limited by attempts to protect structures through the hardening of lagoon shorelines, yet another example of feedback between social and ecological systems. The potential loss of Rhode Island's salt ponds also threatens the sense of place that inspires significant artistic enterprise, e.g., landscape painting (John Lutes), cartooning (Don Bosquet), and literature
(Spartina by John Casey 1989), as well as birding and the seasonal pilgrimage of tourists to beaches along barriers.

\section{Outer Banks and Lowcountry of the Carolinas}

The Carolina Outer Banks are barrier spits that separate a large estuarine system, including Pamlico Sound, the largest Atlantic coastal lagoon, from the Atlantic Ocean (Bailey 1999; Fig. 4). The Carolina Lowcountry consists of a series of lagoons and waterways that extend along the South Carolina coast. Both systems provide habitat for migratory birds, halophilic grasses, finfish, and shellfish (Frankenberg 1997). The Outer Banks and Lowcountry are a transitional cultural setting in which the wealthy compete for coastal land with poorer communities of longstanding historical importance. Islands off the South Carolina coast have been home to generations of African Americans in a unique sea-island culture known as the Gullah in South Carolina and Geechee in Georgia. Gullah-populated islands, including Edisto Island, Coosaw Island, St. Helena Island, and Daufuskie Island, served as the inspiration for the fictional Yamacraw Island in Pat Conroy's (1972) The Water is Wide. The Gullah culture inspired Julia Peterkin's (1928) Pulitzer Prize winning novel Scarlet Sister Mary and the paintings of John W. Jones (Fig. 5B). These works exemplify scholarly and inspirational values (Halfacre et al. 2007).

Sea level increase threatens the low-elevation barriers in this region and will change the hydrology and salinity of the lagoons. The catchment area draining into this lagoon system is relatively large compared to the area of the lagoons (Dame et al. 2000), intensifying the effect of increased precipitation. Nutrients carried with higher 
Fig. 5. Art as a manifestation of the inspirational values of coastal lagoons. (A) Swamp Idyl-Louisiana Bayou Country. Artist: Colette Pope Heldner (used with permission). (B) Gullah Fisherman. Artist: John W. Jones, Lowcountry, South Carolina (used with permission).
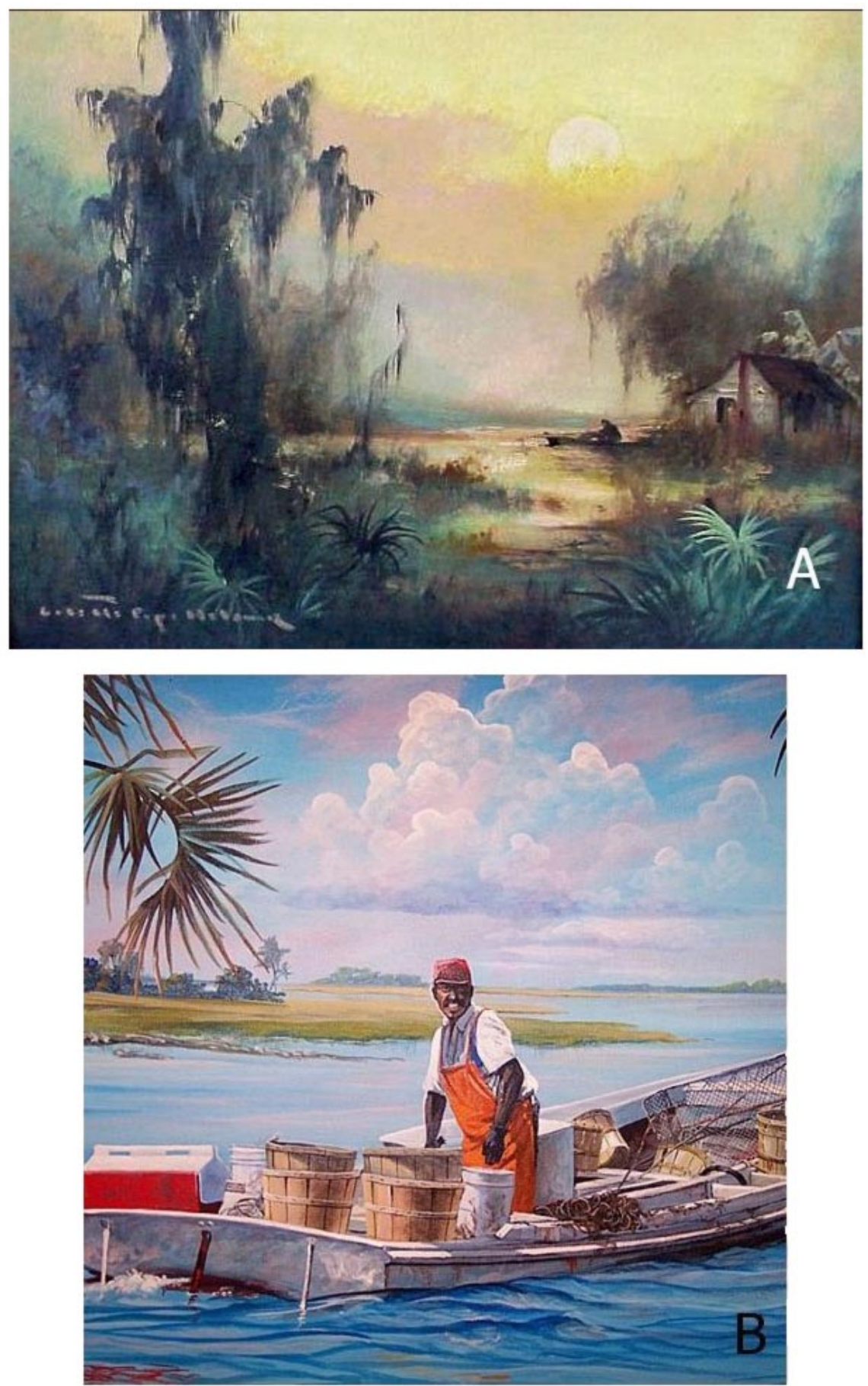
freshwater flows increase the likelihood of eutrophication (Rogers and McCarty 2000), affecting not only pragmatic values associated with fisheries and real estate, but also inspirational and tacit values. These coastal lagoons, including traditional Gullah lands, are threatened by residential and commercial development, which will in turn be threatened by inundation from hurricanes and sea level increase. Residents of low socioeconomic status may not have the capacity to evacuate flood-prone areas during extreme storm events, as was the case with many New Orleans communities during Hurricane Katrina in 2005 (Chakraborty et al. 2005, Lie 2006). Under current climate change projections, the delicate balance between local cultural groups and their lagoon landscapes will be severely disrupted, with the potential for permanent displacement of a singular indigenous culture and language unique to the Gullah (Jarrett and Lucas 2002). A GCC-induced diaspora will diminish the related scholarly, inspirational, and tacit values of these lagoons. In addition, pragmatic and scholarly values are at risk from erosion, sea level increase, hurricanes, and storm surge that threaten significant archaeological sites and other historic landmarks such as the Cape Hatteras lighthouse (Watts 1975, Babits 2002). Contrary to the traditional strategy of responding to coastal erosion by hardening shorelines, protection of the Cape Hatteras lighthouse was achieved through relocation in 1999 (National Research Council 1988, North Carolina State University 1997).

\section{Jamaica Bay, New York}

Jamaica Bay is a coastal lagoon located in one of the most densely developed urban settings in the United States (Fig. 4) and represents the largest natural open space in New York City. As part of the Gateway National Recreation Area (U.S. National Park Service), Jamaica Bay hosts $>6$ million visitors annually (Hoffman 2006) and provides habitat for $>300$ species of migratory and resident birds (Brown et al. 2001), as well as spawning grounds for horseshoe crabs (Botton et al. 2006). The lagoon provides urban residents direct access to a relatively undeveloped natural world and is a living classroom for schoolchildren involved in National Park Service sponsored curricula that link classroom science activities with natural ecosystems.

The salt marshes of Jamaica Bay that provide prime habitat have been receding at an accelerating pace
(Hartig et al. 2002). Although activities such as channel dredging and heavy boat traffic have likely contributed to short-term marsh loss, encroaching sea level increase and increased storminess present long-term hazards to Jamaica Bay's lagoon system (Gornitz et al. 2002). As GCC impacts unfold, urban residents could lose the tacit benefits of this contrasting land and lagoonscape and the calming effects of ambient natural sights, sounds, and textures (Foster 1998).

\section{CONCLUSIONS}

GCC-induced physical and ecological changes to coastal lagoons will force both natural and human communities to adapt. Natural communities may respond in a variety of ways: shifts in community composition and diversity, susceptibility to eutrophication and disease, and localized loss of some native species. However, the ability of natural communities to adapt successfully to changing conditions will be influenced by human actions. For example, proactive protection of undeveloped land surrounding coastal lagoons gives natural communities a better chance for survival through habitat migration, whereas continued shoreline development impedes ecosystem adaptation by limiting salt marsh migration. The former acknowledges and attempts to sustain the complex interaction between human and natural systems, whereas the latter leaves society vulnerable to the loss of the full spectrum of values associated with lagoon ecosystems.

Human communities will necessarily respond to immediate threats and may also plan for anticipated impacts. In the face of these potential impacts, the effective management of coastal lagoons requires an understanding of the social, physical, and ecological processes that collectively influence how lagoons are affected by GCC. Social values such as the desire to preserve a seaside community and its associated way of life may drive responses that produce feedback in lagoon ecosystems. This feedback may be counterproductive for both natural and human communities. Attention to the full spectrum of social values is more likely to prompt the consideration of the widest range of ramifications of any course of action or inaction.

However, management strategies, even those that are ecosystem based, currently do not incorporate quantification of the full spectrum of social values. Because pragmatic values are the easiest to quantify 
and appear to be more absolute and persuasive than other values, they are weighed most heavily in management decisions. By contrast, tacit values are much more difficult to quantify and are often overlooked in coastal management decisions. Ironically, tacit values are the most influential to stakeholders because they both derive from and shape individual experiences and beliefs. They also underpin the full spectrum of social values and can be expected to have strong influence over human behavior. Furthermore, the consideration of tacit values promotes civic engagement in coastal management decision making because these values intersect with the interests and needs of all concerned, regardless of their social, political, or economic influence (Millennium Ecosystem Assessment 2005).

Tools that articulate and quantify tacit values are needed to provide a more balanced data set to coastal managers. The development and interpretation of such tools is dependent upon an interdisciplinary approach that incorporates knowledge both in and beyond the science community (Leslie and McLeod 2007). Fragile coastal lagoons and the societies that depend on them present particularly complex challenges because they are on the frontline facing the most immediate effects of climate change. An appeal to tacit values, which are fundamental to the human experience, may better engage society as managers strive to develop and implement mitigation or adaptation strategies.

Responses to this article can be read online at: http://www.ecologyandsociety.org/voll4/iss 1/art8/responses/

\section{Acknowledgments:}

This research was sponsored by NSF IGERT grant \#0504103 to the University of Rhode Island Coastal Institute. We are grateful to John King, Scott Nixon, Stephen Olsen, Charles Roman, Barry Sullivan, Virginia Lee, Erika Lentz, Barry Costa-Pierce, James Boyd, and Janet Freedman for their help and advice in developing this paper. Our use of the painting of the "Gullah Fisherman" by John W. Jones (author and artist of Confederate Currency: The Color of Money, Images of Slavery in Confederate and Southern States Currency) is used with permission. We thank Nate Dibble for preparing the illustration of a coastal lagoon.

\section{LITERATURE CITED}

Adamowicz, W. L., P. Boxall, M. Williams, and J. Louviere. 1998. Stated preference approaches for measuring passive use values: choice experiments and contingent valuation. American Journal of Agricultural Economics 80:64-75.

Allen, G., E. Mandelli, and J. P. F. Zimmermann. 1981. Physics, geology, chemistry. Pages 29-50 in P. Lasserre and H. Postma, editors. Coastal lagoon research, present and future: proceedings of a seminar. UNESCO Technical Papers in Marine Science 32. United Nations Educational, Scientific, and Cultural Organization, Paris, France.

Anderson, D. M., P. M. Gilbert, and J. M. Burkholder. 2002. Harmful algal blooms and eutrophication: nutrient sources, composition, and consequences. Estuaries and Coasts 25(4):704-746.

Babits, L. E. 2002. Maritime archaeology in North Carolina. Pages 119-126 in C. V. Ruppé and J. Barstad, editors. International handbook of underwater archaeology. Kluwer Academic/ Plenum, New York, New York, USA.

Bailey, A. 1999. The Outer Banks. University of North Carolina Press, Chapel Hill, North Carolina, USA.

Berke, P. R., D. R. Godschalk, E. J. Kaiser, and D. A. Rodriguez. 2006. Urban land use planning. Fifth edition. University of Illinois Press, Urbana, Illinois, USA.

Bertness, M. D. 2007. Atlantic shorelines: natural history and ecology. Princeton University Press, Princeton, New Jersey, USA.

Bilkovic, D. M., and M. M. Roggero. 2008. Effects of coastal development on nearshore estuarine nekton communities. Marine Ecology Progress Series 358:27-39.

Bindoff, N. L., J. Willebrand, V. Artale, A. Cazenave, J. Gergory, S. Gulev, K. Hanawa, C. Le Quéré, S. Levitus, Y. Nojiri, C. K. Shum, L. D. Talley, and A. Unnikrishnan. 2007. Observations: oceanic climate change and sea level. In S. Solomon, D. Qin, M. Manning, Z. Chen, M. Marquis, K. B. Averyt, M. Tignor, and H. L. Miller, editors. Climate change 2007: the physical science basis. Contribution of Working Group I to the 
Fourth Assessment Report of the Intergovernmental Panel on Climate Change. Cambridge University Press, Cambridge, UK. Available online at: http:// www.ipcc.ch/pdf/assessment-report/ar4/wg1/ar4-wg1spm.pdf.

Bird, E. C. F. 1993. Submerging coasts: the effects of a rising sea level on coastal environments. Wiley, Chichester, UK.

Bird, E. C. F. 1994. Chapter 2. Physical setting and geomorphology of coastal lagoons. Pages 9-40 in B. Kjerfve, editor. Coastal lagoon processes. Elsevier, Amsterdam, The Netherlands.

Blintz, J. C., S. Nixon, B. Buckley, and S. Granger. 2003. Impacts of temperature and nutrients on coastal lagoon plant communities. Estuaries 26:765-776.

Boothroyd, J. C., and P. V.August. 2008. Geologic and contemporary landscapes of the Narragansett Bay ecosystem. Pages 1-30 in A. Desbonnet and B. A. Costa-Pierce, editors. Science for ecosystembased management: Narragansett Bay in the 21st century. Springer, New York, New York, USA.

Boothroyd, J. C., N. E. Friedrich, and S. R. McGinn. 1985. Geology of microtidal coastal lagoons: Rhode Island. Marine Geology 63:35-76.

Bopp, L., C. LeQuéré, M. Heimann, A. C. Manning, and P. Monfray. 2002. Climate-induced oceanic oxygen fluxes: implications for the contemporary carbon budget. Global Biogeochemical Cycles 16(2): 1022.

Botton, M. L., R. E. Loveland, J. T. Tanacredi, and T. Itow. 2006. Horseshoe crabs (Limulus polyphemus) in an urban estuary (Jamaica Bay, New York) and the potential for ecological restoration. Estuaries and Coasts 29(5):820-830.

Brandenburg, A. M., and M. S. Carroll. 1995. Your place or mine? The effect of place creation on environmental values and landscape meanings. Society and Natural Resources 8(5):381-398.

Brown, K. M., J. L. Tims, R. M. Erwin, and M. E. Richmond. 2001. Changes in the nesting populations of colonial waterbirds in Jamaica Bay Wildlife Refuge, New York, 1974-1998. Northeastern Naturalist 8(3):275-292.
Brown, T. C., G. L. Peterson, and B. E. Tonn. 1995. The values jury to aid natural resource decisions. Land Economics 71(2):250-260.

Bruun, P. 1962. Sea-level rise as a cause of shore erosion. Journal of the Waterways and Harbors Division 88(1-3):117-130.

Burkett, V. R., D. B. Zilkoski, and D. A. Hart. 2003. Sea level rise and subsidence: implications for flooding in New Orleans, Louisiana. Pages 63-70 in K. R. Prince and D. L. Galloway, editors. U.S. Geological Survey Subsidence Interest Group Conference, Proceedings of the Technical Meeting. U.S. Geological Survey, Water Resources Division Open File Report 03-308.

Casey, J. 1989. Spartina. Knopf, New York, New York, USA.

Cazenave, A., and R. S. Nerem. 2004. Present-day sea level change: observations and causes. Reviews of Geophysics 42: RG3001.

Chabreck, R. H., and A. W. Palmisano. 1973. The effects of Hurricane Camille on the marshes of the Mississippi River delta. Ecology 54(5):1118-1123.

Chakraborty, J., G. A. Tobin, and B. E. Montz. 2005. Population evacuation: assessing spatial variability in geophysical risk and social vulnerability to natural hazards. Natural Hazards Review 6(1):23-33.

Church, J. A., and N. J. White. 2006. A 20th century acceleration in global sea-level rise. Geophysical Research Letters 33: L01602.

Cicin-Sain, B., and R. W. Knecht. 1998. Integrated coastal and ocean management: concepts and practices. Island Press, Washington, D.C., USA.

Committee on Environment and Natural Resources. 2008. Scientific assessment of the effects of global change on the United States. U.S. Climate Change Science Program, Washington, D. C., USA. Available online at: http://www.climatesc ience.gov/Library/scientific-assessment/.

Conley, D. J., J. Carstensen, G. Aertebjerg, P. B. Christensen, T. Dalsgaard, J. L. S. Hansen, and A. B. Josefson. 2007. Long-term changes and impacts of hypoxia in Danish coastal waters. 
Ecological Applications 17(sp5):S165-S184.

Conroy, P. 1972. The water is wide. Houghton Mifflin, Boston, Massachusetts, USA.

Couzin, J. 2008. Living in the danger zone. Science 319:748-749.

Dame, R., M. Alber, D. Allen, M. Mallin, C. Montague, A. Lewitus, A. Chalmers, R. Gardner, C. Gilman, B. Kjerfve, J. Pinckney, and N. Smith. 2000. Estuaries of the south Atlantic coast of North America: their geographical signatures. Estuaries 23(6):793-819.

Darnell, R. M. 1959. Of the life history of the blue crab (Callinectes sapidus rathbun) in Louisiana waters. Transactions of the American Fisheries Society 88(4):294-304.

D’Avanzo, C., and J. N. Kremer. 1994. Diel oxygen dynamics and anoxic events in an eutrophic estuary of Waquoit Bay, Massachusetts. Estuaries 17:131-139.

Davis, R. K. 1963. Recreation planning as an economic problem. Natural Resources Journal 3 (2):239-249.

Day, Jr., J. W., D. F. Boesch, E. J. Clairain, G. P. Kemp, S. B. Laska, W. J. Mitsch, K. Orth, H. Mashriqui, D. J. Reed, L. Shabman, C. A. Simenstad, B. J. Streever, R. R. Twilley, C. C. Watson, J. T. Wells, and D. F. Whigham. 2007. Restoration of the Mississippi Delta: lessons from Hurricanes Katrina and Rita. Science 315:1679-1684.

Dean, R. G. 2006. New Orleans and the wetlands of southern Louisiana. The Bridge 36(1):35-42.

Desvousges, W. H., and V. K. Smith. 1988. Focus groups and risk communication: the "science" of listening to data. Risk Analysis 8(4):479-484.

Donnelly, J. P., and M. D. Bertness. 2001. Rapid shoreward encroachment of salt marsh cordgrass in response to accelerated sea-level rise. Proceedings of the National Academy of Sciences $\mathbf{9 8}$ (25):14218-14223.

Edwards, M., and A. J. Richardson. 2004. Impact of climate change on marine pelagic phenology and trophic mismatch. Nature 430:881-884.

Emanuel, K. 2005. Increasing destructiveness of tropical cyclones over the past 30 years. Nature 436:686-688.

Fenster, M. S., and R. Dolan. 1993. Historical shoreline trends along the Outer Banks, North Carolina: processes and responses. Journal of Coastal Research 9(1):172-188.

Fenster, M., and R. Dolan. 1994. Large-scale reversals in shoreline trends along the U.S. midAtlantic coast. Geology 22(6):543-546.

Fiksen, Ø., D. L. Aksnes, M. H. Flyum, and J. Giske. 2002. The influence of turbidity on growth and survival of fish larvae: a numerical analysis. Hydrobiologia 484(1-3):49-59.

Foster, C. 1998. The narrative and the ambient in environmental aesthetics. Journal of Aesthetics and Art Criticism 56(2):127-137.

Frankenberg, D. 1997. The nature of North Carolina's southern coast: barrier islands, coastal waters, and wetlands. University of North Carolina Press, Chapel Hill, North Carolina, USA.

Freeman III, A. M. 2003. The measurement of environmental and resource values: theory and methods. Second edition. Resources for the Future, Washington, D.C., USA.

Fritz, H. M., C. Blount, R. Sokoloski, J. Singleton, A. Fuggle, B. G. McAdoo, A. Moore, C. Grass, and B. Tate. 2007. Hurricane Katrina storm surge distribution and field observations on the Mississippi barrier islands. Estuarine, Coastal and Shelf Science 74(1-2):12-20.

Frumhoff, P. C., J. J. McCarthy, J. M. Melillo, S. C. Moser, and D. J. Wuebbles. 2007. Confronting climate change in the U.S. northeast: science, impacts, and solutions. Union of Concerned Scientists, Cambridge, Massachusetts, USA. Available online at: http://www.northeastclim ateimpacts.org/pdf/confronting-climate-change-inthe-u-s-northeast.pdf.

Gatter, W. 1992. Zugzeiten und Zugmuster im Herbst: Einfluß des Treibhauseffekts auf den 
Vogelzug? Journal für Ornithologie 133 (4):427-436.

Gomez, G. M. 1998. A wetland biography, seasons on Louisiana's Chenier Plain. First edition. University of Texas Press, Austin, Texas, USA.

Gönenç, I. E., and J. P. Wolflin, editors. 2005. Coastal lagoons: ecosystem processes and modeling for sustainable use and development. CRC Press, Boca Raton, Florida, USA.

Gornitz, V., S. Couch, and E. K. Hartig. 2002. Impacts of sea level rise in the New York City metropolitan area. Global and Planetary Changes 32:61-88.

Graham, L. P., S. Hagemann, S. Jaun, and M. Beniston. 2007. On interpreting hydrological change from regional climate models. Climatic Change 81(S1):97-122.

Gramling, R., and R. Hagelman. 2005. A working coast: people in the Louisiana wetlands. Journal of Coastal Research 44:112-133.

Greening, H., P. Doering, and C. Corbett. 2006. Hurricane impacts on coastal ecosystems. Estuaries and Coasts 29:877-879.

Grimm, N. B., S. H. Faeth, N. E. Golubiewski, C. L. Redman, J. Wu, X. Bai, and J. M. Briggs. 2008. Global change and the ecology of cities. Science 319:756-760.

Gunter, G. 1961. Habitat of juvenile shrimp (Family Penaeidae). Ecology 42(3):598-600.

Gushee, L. 1994. The nineteenth-century origins of jazz. Black Music Research Journal 14(1):1-24.

Halfacre, A. C., D. R. Hitchcock, and J.A. Shuler. 2007. Community associations and stormwater management: a coastal South Carolina perspective. College of Charleston, Charleston, South Carolina, USA. [online] URL: http://www.cofc.edu/ uses/Co mmunityAssociationsAndStormwaterManagement. pdf.

Harley, C. D. G., A. R. Hughes, K. M. Hultgren, B. G. Miner, C. J. B. Sorte, C. S. Thornber, L. F. Rodriquez, L. Tomanek, and S. L. Williams.
2006. The impacts of climate change in coastal marine systems. Ecology Letters 9(2):228-241.

Harris, L. A., B. Buckley, S. W. Nixon, and B. T. Allen. 2004. Experimental studies of predation by bluefish Pomatomus saltatrix in varying densities of seagrass and macroalgae. Marine Ecology Progress Series 281:233-239.

Hartig, E. K., V. Gornitz,A. Kolker, F. Mushacke, and D. Fallon. 2002. Anthropogenic and climatechange impacts on salt marshes of Jamaica Bay, New York City. Wetlands 22(1):71-89.

Hatton, R. S., R. D. DeLaune, and W. H. Patrick, Jr. 1983. Sedimentation, accretion, and subsidence in marshes of Barataria Bay, Louisiana. Limnology and Oceanography 28(3):494-502.

Hayes, M. O. 2005. Barrier islands. Pages 117-119 in M. L. Shwartz, editor. Encyclopedia of coastal science. Springer, Dordrecht, The Netherlands.

Heck, Jr., K. L., and T. A. Thoman. 1984. The nursery role of seagrass meadows in the upper and lower reaches of Chesapeake Bay. Estuaries 7:70-92.

Hoegh-Guldberg, O., P. J. Mumby, A. J. Hooten, R. S. Steneck, P. Greenfield, E. Gomez, C. D. Harvell, P. F. Sale, A. J. Edwards, K. Caldeira, N. Knowlton, C. M. Eakin, R. Iglesias-Prieto, N. Muthiga, R. H. Bradbury, A. Dubi, and M. E. Hatziolos. 2007. Coral reefs under rapid climate change and ocean acidification. Science 318:1737-1742.

Hoffman, P. 2006. Special regulations, areas of the National Parks. Federal Register 71(37):9495-9502.

Holland, G. J., and P. J. Webster. 2007. Heightened tropical cyclone activity in the North Atlantic: natural variability or climate trend? Philosophical Transactions of the Royal Society A: Mathematical, Physical, and Engineering Sciences 365:2695-2716.

Hollister, J. W.,P. V.August, and J. F. Paul. $2008 a$. Effects of spatial extent on landscape structure and sediment metal concentration relationships in small estuarine systems of the United States' mid-Atlantic coast. Landscape Ecology 23(S1):91-106. 
Hollister, J. W., P. V. August, J. F. Paul, and H. A. Walker. 2008b. Predicting estuarine sediment metal concentrations and inferred ecological conditions: an information theoretic approach. Journal of Environmental Quality 37:234-244.

Horppila, J., A. Liljendahl-Nurminen, and T. Malinen. 2004. Effects of clay turbidity and light on the predator-prey interaction between smelts and chaoborids. Canadian Journal of Fisheries and Aquatic Science 61(10):1862-1870.

Howick, G. L., and W. J. O'Brien. 1983. Piscivorous feeding behavior of largemouth bass: an experimental analysis. Transactions of the American Fisheries Society 112(4):508-516.

Hume, D. 1999. An enquiry concerning human understanding. Oxford University Press, Oxford, UK.

Intergovernmental Panel on Climate Change. 2007. Summary for policy makers. In S. Solomon, D. Qin, M. Manning, Z. Chen, M. Marquis, K. B. Averyt, M. Tignor, and H. L. Miller, editors. Climate change 2007: the physical science basis. Contribution of Working Group I to the Fourth Assessment Report of the Intergovernmental Panel on Climate Change. Cambridge University Press, Cambridge, UK. Available online at: http://www.ip cc.ch/pdf/assessment-report/ar4/wg1/ar4-wg1-spm. pdf.

Jarrett, C. W., and D. M. Lucas. 2002. Introducing folknography: a study of Gullah culture. Page 20 in Proceedings of the 65th Annual Meeting of the Rural Sociological Society (Chicago, 2002). Rural Sociological Society, Columbia, Missouri, USA. Abstracts available online at: http://www.ruralsocio logy.org/annual-meeting/2002/.

Joos, F., G.-K. Plattner, T. F. Stocker, A. Körtzinger, and D. W. R. Wallace. 2003. Trends in marine dissolved oxygen: implications for ocean circulation changes and the carbon budget. Eos, Transactions, American Geophysical Union 84 (21):197-207.

Just, R. E., D. L. Hueth, and A. Schmitz. 2004. Welfare economics of public policy: a practical approach to project and policy evaluation. Elgar Edward Publishing, Northampton, Massachusetts, USA.

Justic, D., N. N. Rabalais, and R. E. Turner. 1996.
Effects of climate change on hypoxia in coastal waters: a doubled $\mathrm{CO}_{2}$ scenario for the northern Gulf of Mexico. Limnology and Oceanography 41 (5):992-1003.

Keeney, R. L., and H. Raiffa. 1993. Decisions with multiple objectives: preferences and value tradeoffs. Cambridge University Press, Cambridge, UK.

Keenlyside, N. S., M. Latif, J. Jungclaus, L. Kornblueh, and E. Roeckner. 2008. Advancing decadal-scale climate prediction in the North Atlantic sector. Nature 453(7191):84-88.

Khan, N. Y. 2007. Multiple stressors and ecosystem-based management in the Gulf. Aquatic Ecosystem Health and Management 10(3):259-267.

Kjerfve, B., editor. 1994. Coastal lagoon processes. Elsevier, Amsterdam, The Netherlands.

Kjerfve, B., and K. E. Magill. 1989. Geographic and hydrodynamic characteristics of shallow coastal lagoons. Marine Geology 88(3-4):187-199.

Krippendorff, K. 2004. Content analysis: an introduction to its methodology. Sage Publications, Thousand Oaks, California, USA.

Krutilla, J. V. 1967. Conservation reconsidered. American Economic Review 57(4):777-786.

Landsea, C. W. 2007. Counting Atlantic tropical cyclones back to 1900. Eos, Transactions, American Geophysical Union 88(18):197-202.

Leatherman, S. P. 1981. Overwash processes. Hutchinson Ross Publishing, Stroudsburg, Pennsylvania, USA.

Leatherman, S. P., K. Zhang, and B. C. Douglas. 2000. Sea level rise shown to drive coastal erosion. Eos, Transactions, American Geophysical Union 81 (6):55-59.

Lee, V. 1980. An elusive compromise: Rhode Island coastal ponds and their people. Marine Technical Report 73. University of Rhode Island Coastal Resources Center, Narragansett, Rhode Island, USA.

Leslie, H. M., and K. L. McLeod. 2007. Confronting the challenges of implementing marine ecosystem-based management. Frontiers in 
Ecology and the Environment 5:540-548.

Lie, J. 2006. The last last wave. Du Bois Review: Social Science Research on Race 3(1):233-238.

Lloret, J., A. Marín, and L. Marín-Guirao. 2008. Is coastal lagoon eutrophication likely to be aggravated by global climate change? Estuarine, Coastal and Shelf Science 78(2):403-412.

Mackenzie, B. R., H. Gislason, C. Möllmann, and F. W. Köster. 2007. Impact of 21st century climate change on the Baltic Sea fish community and fisheries. Global Change Biology 13(7):1348-1367.

Malhi, Y., J. T. Roberts, R. A. Betts, T. J. Killeen, W. Li, and C. A. Nobre. 2008. Climate change, deforestation, and the fate of the Amazon. Science 319:169-172.

Mann, M. E., K. A. Emanuel, G. J. Holland, and P. J. Webster. 2007. Atlantic tropical cyclones revisited.Eos, Transactions, American Geophysical Union 88(36):349-350.

Martin, L., and J. M. L. Dominguez. 1994. Chapter 3: Geological history of coastal lagoons. Pages 41-68 in B. Kjerfve, editor. Coastal lagoon processes. Elsevier, Amsterdam, The Netherlands.

Mazzotta, M. J., J. J. Opaluch, and T. A. Grigalunas. 1994. Natural resource damage assessment: the role of resource restoration. Natural Resources Journal 34:153-178.

McComb, A. J., editor. 1995. Eutrophic shallow estuaries and lagoons. CRC Press, Boca Raton, Florida, USA.

McGlathery, K. J. 2001. Macroalgal blooms contribute to the decline of seagrass in nutrientenriched coastal waters. Journal of Phycology 37 (4):453-456.

Meehl, G. A., T. F. Stocker, W. D. Collins, P. Friedlingstein, A. T. Gaye, J. M. Gregory, A. Kitoh, R. Knutti, J. M. Murphy, A. Noda, S. C. B. Raper, I. G. Watterson, A. J. Weaver, and Z. Zhao. 2007. Global climate projections. in $\mathrm{S}$. Solomon, D. Qin, M. Manning, M. Marquis, K. Averyt, M. M. B. Tignor, H. L. Miller, Jr., and Z. Chen, editors. Climate change 2007: the physical science basis. Contribution of Working Group I to the Fourth Assessment Report of the Intergovernmental Panel on Climate Change. Cambridge University Press, Cambridge, UK. Available online at: http:// www.ipcc.ch/ipccreports/ar4-wg1.htm.

Mendelssohn, I. A., and K. L. McKee. 1988. Spartina alterniflora die-back in Louisiana: timecourse investigation of soil waterlogging effects. Journal of Ecology 76(2):509-521.

Michener, W. K., E. R. Blood, K. L. Bildstein, M. M. Brinson, and L. R. Gardner. 1997. Climate change, hurricanes and tropical storms, and rising sea level in coastal wetlands. Ecological Applications 7(3):770-801.

Millennium Ecosystem Assessment. 2005. Ecosystems and human well-being: general synthesis. Island Press, Washington, D.C., USA. Available online at: http://www.millenniumassessment. org/documents/document.356.aspx.pdf.

Milly, P. C. D., K. A. Dunne, and A. V. Vecchia. 2005. Global pattern of trends in streamflow and water availability in a changing climate. Nature 438 (7066):347-350.

Mitchell, R. C., and R. T. Carson. 1989. Using surveys to value public goods: the contingent valuation method. Resources for the Future, Washington, D.C., USA.

Morton, R. A., and A. H. Sallenger, Jr. 2003. Morphological impacts of extreme storms on sandy beaches and barriers. Journal of Coastal Research 19(3):560-573.

Najjar, R. G., H. A. Walker, P. J. Anderson, E. J. Barron, R. J. Bord, J. R. Gibson, V. S. Kennedy, C. G. Knight, J. P. Megonigal, R. E. O'Connor, C. D. Polsky, N. P. Psuty, B. A. Richards, L. G. Sorenson, E. M. Steele, and R. S. Swanson. 2000. The potential impacts of climate change on the midAtlantic coastal region. Climate Research $\mathbf{1 4}$ (3):219-233.

National Oceanic and Atmospheric Administration Coastal Services Center. 2007. Social science tools for coastal programs: introduction to stakeholder participation. National Oceanic and Atmospheric Administration Coastal Services Center, Charleston, South Carolina, USA. Available online at: http://w ww.csc.noaa.gov/cms/human dimensions/ 
$\underline{\text { Stakeholder Participation Guidance Document.pdf }}$

National Research Council. 1988. Saving Cape Hatteras lighthouse from the sea: options and policy implications. National Academy Press, Washington, D.C., USA.

National Research Council. 2000. Clean coastal waters: understanding and reducing the effects of nutrient pollution. National Academy Press, Washington, D.C., USA.

National Research Council. 2005. Valuing ecosystem services: toward better environmental decision-making. National Academy Press, Washington, D.C., USA.

Naukkarinen, O. 1998. Aesthetics of the unavoidable: aesthetic variations in human appearance. Gummerus Kirjapaino Oy, Saarijarvi, Finland.

Nichols, M. M., and J. D. Boon III. 1994. Chapter 7. Sediment transport processes in coastal lagoons. Pages 157-219 in B. Kjerfve, editor. Coastal lagoon processes. Elsevier, Amsterdam, The Netherlands.

Ning, Z. H., and K. Abdollahi. 2003. Gulf Coast regional climate. Pages 79-82 in Z. H. Ning, R. E. Turner, T. Doyle, and K. Abdollahi, editors. Integrated assessment of the climate change impacts on the Gulf Coast region. Gulf Coast Climate Change Assessment Council and Louisiana State University Graphic Services, Washington, D. C., USA. Available online at: http://www.usgcrp.gov/ usgcrp/Library/nationalassessment/gulfcoast/.

Nixon, S. W. 1982. Nutrient dynamics, primary production and fisheries yields of lagoons. Pages 357-371 in P. Lasserre and H. Postma, editors. Coastal lagoons: proceedings of the International Symposium on Coastal Lagoons (Bordeaux, France, 1981). Oceanologica Acta 4(Supplement). GauthierVillars, Paris, France.

Nixon, S. W. 1995. Coastal marine eutrophication: a definition, social causes, and future concerns. Ophelia 41:199-219.

Nixon, S. W., S. Granger, and B.A. Buckley. 2003. The warming of Narragansett Bay. $41^{\circ} N$ 2(1): 19-20. Available online at: http://seagrant.gso.uri.e
du/41N/Vol2No1/index.html.

Nixon, S. W., S. Granger, B. A. Buckley, M. Lamont, and B. Rowell. 2004. A one hundred and seventeen year coastal water temperature record from Woods Hole, Massachusetts. Estuaries 27 (3):397-404.

Nixon, S. W., and C. A. Oviatt. 1972. Preliminary measurements of midsummer metabolism in beds of eelgrass, Zostera marina. Ecology $\mathbf{5 3}$ (1):150-153.

North Carolina State University. 1997. North Carolina State University 1997 Review and Update of the 1988 National Research Council Report. North Carolina State University, Raleigh, North Carolina, USA. Available online at: http://www.nps. gov/archive/caha/1997update.htm.

Ogburn, M. B., and M. Alber. 2006. An investigation of salt marsh dieback in Georgia using field transplants. Estuaries and Coasts 29(1):54-62.

Oliveira, A., A. B. Fortunato, and J. R. L. Rego. 2006. Effect of morphological changes on the hydrodynamics and flushing properties of Óbidos lagoon (Portugal). Continental Shelf Research 26 (8):917-942.

Oouchi, K., J. Yoshimura, H. Yoshimura, R. Mizuta, S. Kusunoki, and A. Noda. 2006. Tropical cyclone climatology in a global-warming climate as simulated in a $20 \mathrm{~km}$-mesh global atmospheric model: frequency and wind intensity analysis. Journal of the Meteorological Society of Japan $\mathbf{8 4}$ (2):259-276.

Orpin, A. R., P. V. Ridd, and L. K. Stewart. 1999. Assessment of the relative importance of major sediment-transport mechanisms in the central Great Barrier Reef lagoon. Australian Journal of Earth Sciences 46(6):883-896.

Overpeck, J. T., B. L. Otto-Bliesner, G. H. Miller, D. R. Muhs, R. B. Alley, and J. T. Kiehl. 2006. Paleoclimatic evidence for future ice-sheet instability and rapid sea-level rise. Science 311:1747-1750.

Oviatt, C. A. 2004. The changing ecology of temperate coastal waters during a warming trend. Estuaries 27(6):895-904. 
Paerl, H. W., L. M. Valdes, A. R. Joyner, B. L. Peierls, M. E. Piehler, S. R. Riggs, R. R. Christian, L. A. Eby, L. B. Crowder, J. S. Ramus, E. J. Clesceri, C. P. Buzzelli, and R. A. Luettich, Jr. 2006. Ecological response to hurricane events in the Pamlico Sound system, North Carolina, and implications for assessment and management in a regime of increased frequency. Estuaries and Coasts 29(6): 1033-1045.

Peterkin, J. M. 1928. Scarlet sister Mary. Grosset \& Dunlap, New York, New York, USA.

Phleger, F. B. 1981. A review of some general features of coastal lagoons. Pages 7-14 in Coastal lagoon research, present and future: proceedings of a seminar. UNESCO Technical Papers in Marine Science 33. United Nations Educational, Scientific, and Cultural Organization, Paris, France.

Pilkey, O. H., and J. A. G. Cooper. 2004. Society and sea level rise. Science 303:1781-1782.

Pilson, M. E. Q. 1998. An introduction to the chemistry of the sea. Prentice Hall, Upper Saddle River, New Jersey, USA.

Rahmstorf, S. 2007. A semi-empirical approach to projecting future sea-level rise. Science 315:368-370.

Randall, A., B. Ives, and C. Eastman. 1974. Bidding games for valuation of aesthetic environmental improvements. Journal of Environmental Economics and Management 1(2):132-149.

Rodney, A. 1970. Effects of hurricanes Camille and Laurie on the Barataria Bay estuary. Louisiana State University Coastal Studies Institute Bulletin 4:1-16.

Rodriguez, W., P. V. August, Y. Wang, J. F. Paul, A. Gold, and N. Rubinstein. 2007. Empirical relationships between land use/cover and estuarine condition in the northeastern United States. Landscape Ecology 22(3):403-417.

Rogers, C. E., and J. P. McCarty. 2000. Climate change and ecosystems of the mid-Atlantic region. Climate Research 14(3):235-244.

Rolston III, H. 1994. Environmental ethics: values in and duties to the natural world. Pages 65-84 in L. Gruen and D. Jamieson, editors. Reflecting on nature: readings in environmental philosophy. Oxford University Press, New York, New York, USA.

Rosenzweig, C., G. Casassa, D. J. Karoly, A. Imeson, C. Liu, A. Menzel, S. Rawlins, T. L. Root, B. Seguin, and P. Tryjanowski. 2007. Assessment of observed changes and responses in natural and managed systems. Pages 79-131 in M. Parry, O. Canziani, J. Palutikof, P. van der Linden, and C. Hanson, editors. Climate change 2007: impacts, adaptation and vulnerability. Contribution of Working Group II to the Fourth Assessment Report of the Intergovernmental Panel on Climate Change. Cambridge University Press, Cambridge, UK. Available online at: http://www.ipcc.ch/ipccreports/ ar4-wg2.htm.

Royal Society. 2005. Ocean acidification due to increasing atmospheric carbon dioxide. Royal Society Policy Document 12/05. Royal Society, London, UK. Available online at: http://royalsociety. org/document.asp?id=3249.

Rozas, L. P., and D. J. Reed. 1993. Nekton use of marsh-surface habitats in Louisiana (USA) deltaic salt marshes undergoing submergence. Marine Ecology Progress Series 96:147-157.

Ryan, R. L. 2005. Comparing the attitudes of local residents, planners, and developers about preserving rural character in New England. Landscape and Urban Planning 75:5-22.

Sastry, A. N. 1963. Reproduction of the bay scallop, Aequipecten irradians lamarck: influence of temperature on maturation and spawning. Biological Bulletin 125(1):146-153.

Scavia, D., J. C. Field, D. F. Boesch, R. W. Buddemeier, V. Burkett, D. R. Cayan, M. Fogarty, M. A. Harwell, R. W. Howarth, C. Mason, D. J. Reed, T. C. Royer, A. H. Sallenger, and J. G. Titus. 2002. Climate change impacts on U.S. coastal and marine ecosystems. Estuaries 25:149-164.

Serreze, M. C., M. M. Holland, and J. Stroeve. 2007. Perspectives on the Arctic's shrinking sea-ice cover. Science 315:1533-1536.

Short, F. T., and H. A. Neckles. 1999. The effects of global climate change on seagrasses. Aquatic 
Botany 63(3-4):169-196.

Simas, T., J. P. Nunes, and J. G. Ferreira. 2001. Effects of global climate change on coastal salt marshes. Ecological Modeling 139(1):1-15.

Smith, D. M., S. Cusack, A. W. Colman, C. K. Folland, G. R. Harris, and J. M. Murphy. 2007. Improved surface temperature prediction for the coming decade from a global climate model. Science 317: 796-799.

Smith, N. P. 1994. Chapter 4. Water, salt, and heat balances of coastal lagoons. Pages 69-101 in B. Kjerfve, editor. Coastal lagoon processes. Elsevier, Amsterdam, The Netherlands.

Spaulding, M. L. 1994. Chapter 5. Modeling of circulation and dispersion in coastal lagoons. Pages 103-131 in B. Kjerfve, editor. Coastal lagoon processes. Elsevier, Amsterdam, The Netherlands.

Stachowicz, J. J., J. R. Terwin, R. B. Whitlatch, and R. W. Osman. 2002. Linking climate change and biological invasions: ocean warming facilitates nonindigenous species invasions. Proceedings of the National Academy of Sciences 99(24):15497-15500.

Steward, J. S., R. W. Virnstein, M. A. Lasi, L. J. Morris, J. D. Miller, L. M. Hall, and W. A. Tweedale. 2006. The impacts of the 2004 hurricanes on hydrology, water quality, and seagrass in the Central Indian River Lagoon, Florida. Estuaries and Coasts 29(6):954-965.

Swenson, E. M. 2003. Assessing the potential climate change impact on salinity in the northern Gulf of Mexico estuaries: a test case in the Barataria estuarine system. Pages 131-150 in Z. H. Ning, R. E. Turner, T. Doyle, and K. Abdollahi, editors. Integrated assessment of the climate change impacts on the Gulf Coast region. Gulf Coast Climate Change Assessment Council and Louisiana State University Graphic Services, Washington, D. C., USA. Available online at: http://www.usgcrp.gov/ usgcrp/Library/nationalassessment/gulfcoast/.

Taylor, P. W. 1986. Respect for nature: a theory of environmental ethics. Princeton University Press, Princeton, New Jersey, USA.

Tidwell, M. 2003. Bayou farewell: the rich life and tragic death of Louisiana's Cajun coast. First edition. Pantheon Books, New York, New York,
USA.

Titus, J. G. 1990. Greenhouse effect, sea level rise, and barrier islands: case study of Long Beach Island, New Jersey. Coastal Management 18:65-90.

Titus, J. G. 1998. Rising seas, coastal erosion, and the takings clause: how to save wetlands and beaches without hurting property owners. Maryland Law Review 57:1279-1399.

Titus, J. G., and C. Richman. 2001. Maps of lands vulnerable to sea level rise: modeled elevations along the US Atlantic and Gulf coasts. Climate Research 18(3):205-228.

Tomanek, L., and G. N. Somero. 1999. Evolutionary and acclimation-induced variation in the heat-shock responses of congeneric marine snails (genus Tegula) from different thermal habitats: implications for limits of thermotolerance and biogeography. Journal of Experimental Biology 202(21):2925-2936.

Trenberth, K. E., P. D. Jones, P. Ambenje, R. Bojariu, D. Easterling, A. Klein Tank, D. Parker, F. Rahimzadeh, J. A. Renwick, M. Rusticucci, B. Soden, and P. Zhai. 2007. Observations: surface and atmospheric climate change. Pages in S. Solomon, D. Qin, M. Manning, M. Marquis, K. Averyt, M. M. B. Tignor, H. L. Miller, Jr., and Z. Chen, editors. Climate change 2007: the physical science basis. Contribution of Working Group I to the Fourth Assessment Report of the Intergovernmental Panel on Climate Change. Cambridge University Press, Cambridge, UK. Available online at: http:// www.ipcc.ch/ipccreports/ar4-wg1.htm.

Turner, R. E. 2003. Coastal ecosystems of the Gulf of Mexico and climate change. Pages 85-103 in Z. H. Ning, R. E. Turner, T. Doyle, and K. K. Abdollahi, editors. Integrated assessment of the climate change impacts on the Gulf Coast region. Gulf Coast Climate Change Assessment Council and Louisiana State University Graphic Services, Washington, D.C., USA. Available online at: http:/ /www.usgcrp.gov/usgcrp/Library/nationalassessment/ gulfcoast/.

Union of Concerned Scientists. 2006. Climate change in the U.S. Northeast: a report of the Northeast Climate Impacts Assessment. UCS Publications, Cambridge, Massachusetts, USA. Available online at: http://www.climatechoices.org/ 
assets/documents/climatechoices/NECIA climate report final.pdf.

U.S. Environmental Protection Agency. 2007. National coastal condition report II. Publication 620/R-03/002. USEPA Office of Wetlands, Oceans and Watersheds, Washington, D.C., USA. Available online at: http://www.epa.gov/owow/oceans/ nccr/2005/downloads.html.

Valiela, I. 1995. Marine ecological processes. Second edition. Springer, New York, New York, USA.

Valiela, I., K. Foreman, M. Lamontagne, D. Hersh, J. Costa, P. Peckol, B. Demeo-Andreson, C. D'Avanzo, M. Babione, C.-H. Sham, J. Brawley, and K. Lajtha. 1992. Couplings of watersheds and coastal waters: sources and consequences of nutrient enrichment in Waquoit Bay, Massachusetts. Estuaries 15:443-457.

Vecchi, G. A., and B. J. Soden. 2007. Increased tropical Atlantic wind shear in model projections of global warming. Geophysical Research Letters 34: L08702.

Vinebrooke, R. D., K. L. Cottingham, J. Norberg, M. Scheffer, S. I. Dodson, S. C. Maberly, and U. Sommer. 2004. Impacts of multiple stressors on biodiversity and ecosystem functioning: the role of species co-tolerance. Oikos 104(3):451-457.

Watts, Jr., G. P. 1975. The location and identification of the ironclad USS Monitor. International Journal of Nautical Archaeology 4 (2):301-329.

Wazniak, C. E., M. R. Hall, T. J. B. Carruthers, B. Sturgis, W. C. Dennison, and R. J. Orth. 2007. Linking water quality to living resources in a midAtlantic lagoon system, USA. Ecological Applications 17(5S):S64-S78.

Webster, P. J., G. J. Holland, J. A. Curry, and H.R. Chang. 2005. Changes in tropical cyclone number, duration, and intensity in a warming environment. Science 309:1844-1846.

Wengraf, T. 2001. Qualitative research interviewing: biographic narrative and semi-structured methods. Sage Publications, Thousand Oaks, California, USA.
Whittaker, R. H. 1975. Communities and ecosystems. Second edition. MacMillan, New York, New York, USA.

Wilby, F. B., G. R. Young, C. H. Cunningham, A. C. Lieber, Jr., R. K. Hale, T. Saville, and M. P. O'Brien. 1939. Inspection of beaches in path of the hurricane of 21 September 1938. Shore and Beach 7:43-47.

Williams, B. 1994. Must a concern for the environment be centered on human beings? Pages 46-52 in L. Gruen and D. Jamieson, editors. Reflecting on nature: readings in environmental philosophy. Oxford University Press, New York, New York, USA.

Wilsey, B. J., K. L. McKee, and I. A. Mendelssohn. 1992. Effects of increased elevation and macro- and micronutrient additions on Spartina alterniflora transplant success in salt-marsh dieback areas in Louisiana. Environmental Management 16 (4):505-511.

Woodward, F. I. 1987. Climate and plant distribution. Cambridge University Press, Cambridge, UK.

Zhang, K., B. C. Douglas, and S. P. Leatherman. 2004. Global warming and coastal erosion. Climatic Change 64(1-2):41-58.

Zimmerman, J. T. F. 1981. The flushing of wellmixed tidal lagoons and its seasonal fluctuation. Pages 15-26 in P. Lasserre and H. Postma, editors. Coastal lagoon research, present and future: proceedings of a seminar. UNESCO Technical Papers in Marine Science 32. United Nations Educational, Scientific, and Cultural Organization, Paris, France. 
APPENDIX 1. Social science-based methods for assessing values.

Social scientists have developed a variety of methods that are capable of assessing all four classifications of value with varying degrees of quantification. Clearly, this literature is far too extensive to be discussed in any detail. Rather, we briefly summarize some available methods in an attempt to give a flavor of the range of techniques available to assess values, with key references to the literature.

Some methods have rigorous conceptual foundations for value, whereas others are indicators of value, rather than measures of value. All methods have limitations. Commonly, methods with greater conceptual rigor might be more capable of providing quantitative measures of value, which are more easily incorporated into management decisions. However, these approaches might not be as appropriate when applied to values that are less tangible in nature and therefore inherently less quantifiable. In contrast, qualitative methods may be more pertinent to characterizing these latter types of value, but it may be more difficult to use these qualitative assessments to support practical management decisions.

Planning and architects

Community planners, landscape architects, and site designers sometimes use systematic methods of eliciting and assessing the values of a given community or user group. Such methods include visual preference surveys that measure individual preferences for different landscapes, architectural styles, or visual attributes of natural features such as a lagoon (e.g., Ryan 2005). A related method is visualization or visual impact assessment, through which potential changes to a given landscape are modeled via graphic simulation as a means of helping a community evaluate different planning or development scenarios (Berke et al. 2006). One example would be to show visualizations depicting how a lagoon is projected to change through natural processes and what the lagoon would look like under alternative development scenarios or alternative policies.

Charrettes are collaborative public workshops that use an interactive approach to elicit values (Berke et al. 2006, National Oceanic and Atmospheric Administration Coastal Services Center 2007). Issues and concerns raised in charrettes are used to identify important stakeholder values, thereby making social values an integral part of the planning process. Charrettes also improve stakeholder communication, which can aid in developing a shared vision and building consensus. Charrettes are used primarily to engage interested parties in a decision-making process, but do not usually produce quantitative assessments of value. Thus, this method of assessing values is primarily qualitative.

\section{Economics}

Economic methods of valuation are based on a rigorous conceptual foundation of individual preferences. Although economic values are most commonly expressed in dollar terms, economic theory also provides relative preferences over commodities (e.g., Mazzotta et al. 1994). The two primary methods for assessing economic values can be categorized into revealed preference methods and stated preference methods (e.g., Freeman 2003). Revealed preference approaches are based on inferring value from actual choices made by people, typically within market contexts (e.g., Just et al. 2004). Early work in revealed preference methods was based on valuing "consumer's surplus," or the excess in value above and beyond the purchase price of an object. Environmental economists extended market-based approaches to include "related markets" approaches such as the travel cost method or the hedonic price method (e.g., Freeman 2003). Related markets approaches are applied when a commodity such as a recreational fishing trip to a lagoon is not directly sold in the marketplace. Instead, a closely related "good" is used to estimate cost. For example, the travel cost approach uses the cost of accessing a recreational site as the price of "purchasing" the recreational activity. This cost is used as a substitute for the market price for the commodity. The value of a recreational experience is inferred by observing how participation rates vary as the cost of participating varies. The hedonic price approach relates the purchase price of a commodity such as a house to the environmental amenities in the surrounding area. If housing buyers 
desire high levels of environmental quality such as views of a pristine lagoon, they will be willing to pay more for a house located on such a site compared to a house that is identical in all ways but is located on a site with lower environmental quality such as one without a view of a lagoon. The additional amount that consumers are willing to pay to live on a site of higher environmental quality is indicative of one component of the value of improved quality, i.e., that accruing to local homeowners.

Stated preference methods are typically survey based, and respondents are asked a series of hypothetical questions that are used to infer values (e.g., Mitchell and Carson 1989). State-of-the-art surveys are developed and pre-tested with extensive use of focus groups, which are used to identify what potential respondents understand about the stated commodity, what information they require to provide meaningful answers, and what is the most effective format and wording for questions (Desvousges and Smith 1988).

Early stated preference methods were based on the so-called contingent valuation method, which is a direct questioning approach in which the survey determines the maximum amount of money the respondent would pay for some stated commodity (e.g., Davis 1963, Randall et al. 1974). For example, a survey may be conducted to measure an individual's willingness to pay for being able to take walks around a lagoon. Later applications of contingent valuation techniques include referendum-based approaches in which individuals are asked whether they would vote for a hypothetical program to provide some stated commodity at a stated price. For example, respondents might be asked whether they would vote for or against a program to restore eelgrass in a lagoon at some indicated cost to them, often in terms of higher taxes.

"Choice-based" economic valuation methods lay out a series of two or more options, described in terms of a set of characteristics, and ask respondents to indicate which option they would select (e.g.,

Adamowicz et al. 1998). For example, a choice-based survey might ask respondents whether they would choose a program to protect a stated lagoon ecosystem at a given cost, or whether they would prefer an alternative program that might restore damaged wetlands. Statistical methods are used to determine how each characteristic affects the likelihood that individuals select an alternative, thereby providing a quantitative measure of the relative importance that the individuals place on each characteristic. This allows researchers to calculate relative values of different attributes. If the cost of the alternative is one attribute, then the researchers can calculate the implicit monetary value of the attributes, i.e., the relative value of a unit increase in the attribute versus a unit increase in cost. For example, if the commodity in question is a recreational fishing trip and two attributes are the catch rate and the cost of participating, the approach can be used to estimate the rate at which individuals are willing to trade off increased cost for increased catch rate, giving the dollar value of increased recreational catch.

In principle, stated preference methods can be used to calculate values associated with virtually any commodity, including values that are normally thought to be difficult or impossible to monetize. In practice, of course, valuation is complicated by issues such as the hypothetical nature of the transaction and the lack of knowledge about, or experience with, the commodity in question (e.g., Mitchell and Carson 1989).

\section{Sociology and psychology}

Social and psychological valuation methods characterize values using individuals' expressions of the relative importance of different amenities. These are primarily qualitative methods that are most typically based on ordinal rankings (most important vs. less important) or rough interval-scale measures of differences in assessed values. These methods are generally implemented using interview techniques such as individual narratives, semi-structured interviews, or formal surveys (e.g., Brandenburg and Carroll 1995, Wengraf 2001).

A range of tools are used to analyze interviews. For example, content analysis systematically identifies keywords and causal structures in written or spoken text based on the assumption that the most 
commonly used words, phrases, and ideas in a communication reflect the most important considerations (e.g., Krippendorff 2004). A researcher might ask a series of open-ended questions to homeowners to identify the most important values that they hold for a lagoon. The responses could be analyzed using content analysis to identify the number of times certain words, phrases, or concepts are mentioned. The researcher then assumes that the values that are referred to a large number of times are most important, whereas values that are rarely or never mentioned are less important. Formal surveys commonly use Likert scales to identify the strength of agreement that respondents have to a set of statements. For example, one statement in a survey might say "I enjoy living near a lagoon because I am inspired by the beautiful views," and respondents would indicate the extent to which they agree with the statement on a five-point scale ranging from "strongly agree" to "strongly disagree." Responses can be used to calculate an index or scale that measures the relative importance of different values associated with the lagoon.

Social/civic valuation is used to measure values that groups place on amenities. For example, the results of an actual public referendum might be used to determine if the majority of voters feel that protecting a lagoon is worth what it will cost to do so. Questionnaires are sometimes used as a follow up to a referendum to get additional information.

Alternatively, hypothetical questions are sometimes posed to groups to elicit civic values. For example, focus groups might be convened to discuss lagoons to obtain a better understanding of the values that participants hold for lagoons. However, given the small number of participants, focus group are not typically used to assess values per se, but rather are more commonly used to identify the value or suite of values that may be most important. Focus groups might also be used as a preliminary stage in the development of a more rigorous method of eliciting values such as a survey. "Citizen juries" comprising representative members of the public could be presented with extensive information on the ecosystem functions and services associated with coastal lagoons (e.g., Brown et al. 1995). Juries are then asked to deliberate to decide whether it is worthwhile to carry out a program to protect or restore a lagoon, with a particular outcome being achieved at a stated cost to the community.

\section{Decision sciences}

Decision scientists have developed a host of methods to help improve decision making. One method for eliciting values is multiattribute utility (MAU) theory, which is based on the notion that in complex and unfamiliar situations, values are constructed as part of the decision process (Keeney and Raiffa 1993). MAU theory attempts to simplify the cognitive task of constructing values by using an intensive survey approach that probes the decision maker with carefully structured questions that require a respondent to trade off characteristics against each other, thereby eliciting importance ranks and weights. 